\title{
中始新世晚期以来东亚气候变化的渭河盆地 黏土矿物记录
}

\author{
吕恒志 ${ }^{1}$, 鹿化煌 ${ }^{*}$, 王逸超 ${ }^{1}$, 张瀚之 ${ }^{1}$, 王珧 ${ }^{1}$, 王可欣 ${ }^{1}$, 赖文 ${ }^{1}$, 刘志飞 ${ }^{2}$, 李艳丽 ${ }^{2}$, \\ 季峻峰 ${ }^{3}$
}

1. 南京大学关键地球物质循环前沿科学中心, 南京大学地理与海洋科学学院, 南京 210023 ;

2. 同济大学海洋地质国家重点实验室, 同济大学海洋与地球科学学院, 上海 200092 ;

3. 南京大学表生地球化学教育部重点实验室, 南京大学地球科学与工程学院, 南京 210023

*通讯作者, E-mail: huayulu@nju.edu.cn

收稿日期: 2020-12-29; 收修改稿日期: 2021-05-03; 接受日期: 2021-06-07; 网络版发表日期: 2021-07-26

国家自然科学基金项目(批准号: 41888101、41690111、41991320、41920104005)资助

\begin{abstract}
摘要 获得新生代连续的东亚气候变化记录, 是认识东亚气候变化和季风起源、演化及其驱动机制的关键. 文章 基于渭河盆地连续的新生代河湖相沉积序列, 开展黏土矿物含量及晶体参数研究, 重建了中始新世晚期以来东亚 气候变化过程. 结果表明, 蒙㿝石、伊利石是渭河盆地河湖相沉积物中的主要黏土矿物; 伊利石结晶度、伊利石 化学指数、蒙㿝石与伊利石和绿泥石比例的阶段性降低, 指示了在半干旱半湿润的气候背景下, 中始新世晚期以 来渭河流域化学风化阶段性减弱的特征. 坡缕石的形成可能受到成岩作用影响, 相应时期流域风化导致的蒙㿝石 含量和伊利石结晶度实际可能更高. 以上结果表明, 中始新世晚期到上新世渭河盆地可能处于一个相对暖湿的气 候条件. 随着新生代全球温度降低和渭河盆地沉积物的不断加积, 渭河盆地的化学风化强度阶段性减弱, 东亚季 风气候阶段性演化并在第四纪变干. 黏土矿物的证据还表明, 渭河盆地晚始新世到渐新世气候变干, 可能是对全 球变冷事件(EOT转型)的响应.
\end{abstract}

关键词新生代, 渭河盆地, 黏土矿物, 古气候, 东亚季风

\section{1 引言}

随着全球大气温室气体浓度的上升，未来气候可 能是新生代以来温暖期的重现(Tierney等, 2020). 亚洲 深受季风气候影响，理解新生代亚洲季风的起源、演 化和驱动机制, 对于预测未来气候环境变化有重要的 意义. 新生代亚洲地形和全球温度经历了一系列阶段
性变化, 大气环流不断调整，气候纬度地带性趋于明 显，季风形成(Guo等，2002，2008; Sun和Wang，2005; Licht等, 2014; Lu, 2015; Roe等, 2016; 郭正堂, 2017; 鹿 化煜等, 2018). 以中国黄土、红黏土为基础的大量关 于东亚季风的研究表明，从大约 2.6Ma(Ding等，1992; Liu和Ding, 1998; Lu等, 2021)、8 7Ma(Ding等, 1998; Sun等，1998; An，2000)乃至25 22Ma(Guo等，2002，

\footnotetext{
中文引用格式: 吕恒志, 鹿化显, 王逸超, 张瀚之, 王珧, 王可欣, 赖文, 刘志飞, 李艳丽, 季峻峰. 2021. 中始新世晚期以来东亚气候变化的渭河盆地黏土矿物记 录. 中国科学: 地球科学, 51(10): 1722-1741, doi: 10.1360/SSTe-2020-0369

英文引用格式: Lyu H, Lu H, Wang Y, Zhang H, Wang Y, Wang K, Lai W, Liu Z, Li Y, Ji J. 2021. East Asian paleoclimate change in the Weihe Basin (central China) since the middle Eocene revealed by clay mineral analysis. Science China Earth Sciences, 64(8): 1285-1304, https://doi.org/10.1007/s11430-0209799-6
} 
2008)东亚季风开始发育. 然而，一些植物化石、煤层 与蒸发岩、动物化石及同位素的研究认为, 季风起源 可能更早(Quan等, 2011, 2012a, 2012b, 2014; Wang D 等, 2013; Licht等, 2014; Spicer等, 2016; Bougeois等, 2018; Caves Rugenstein和Chamberlain, 2018; Ma等, 2019).

前人对于新生代陆相古气候记录的研究主要集中 于风成沉积及陆相盆地沉积. 中国北方保存的良好的 风成沉积序列以晚渐新世以来为主(Guo等，2002, 2008; 王先彦等, 2006; Lu等, 2010; 强小科等, 2010), 古近纪连续的气候演化记录少. 已研究的陆相盆地多 数远离季风影响区, 比如, 西宁盆地(Dupont-Nivet等, 2007; Xiao等, 2010; 龙利群等, 2011; Zhang和Guo, 2014; Fang等, 2015; 胡涁等, 2019)、塔里木盆地(Wang C等，2013b)、兰州盆地(岳乐平等，2000; 邓焰平等, 2010; Ao等, 2020)、酒泉盆地(苗运法等, 2008)、柴达 木盆地(Song等, 2013, 2018; Ye等, 2018)、准噶尔盆地 (Zhang等, 2012; Sun等, 2014)等, 这些盆地受其他因素 影响, 可能不是季风长期演化的准确记录. 而位于季风 区的盆地大多仅保存了较为片段的沉积记录, 比如, 以 古近纪沉积为主的南阳盆地(朱敏等, 2010)和以新近 纪沉积为主的天水盆地(张军等, 2011), 难以揭示新生 代季风气候演化的全貌.

综上所述，东亚气候和东亚季风长期变化的特征 和驱动机制还存在较大的不确定性, 主要是因为沉积 记录不连续以及气候替代性指标不确定. 渭河盆地位 于现代亚洲季风降水影响边缘区，远离青藏高原，包 含从始新世红河组到更新世三门组完整的沉积序列. 因此，渭河盆地沉积是揭示新生代东亚气候演化过程 的良好材料. 结合渭河盆地的沉积地层、哺乳动物化 石、花粉等记录，获得了对东亚古气候和东亚季风演 化特征和影响因素的框架认识(孙文峰等, 2017; 鹿化 暗等, 2018; 赵琳等, 2018; Wang等, 2019; Wang等, 2020; Zhao等, 2020).

沉积物黏土矿物是受气候控制的风化作用的产 物, 在多种沉积物中含量丰富. 已有不少研究利用新生 代河湖相沉积(Zhang和Guo, 2014; Liu等, 2020)、风成 沉积(季峻峰等, 1997; Gylesjö和Arnold, 2006; 郭正堂 和彭淑贞, 2007; Li 等, 2018)、海洋沉积(Wan等, 2007; Clift等, 2014; Liu等, 2016)等的黏土矿物重建古气候, 获得了黏土矿物组合反映气候环境的新认识. 本文利
用黏土矿物组合重建渭河盆地新生代古气候变化, 尝 试揭示东亚新生代气候变化概貌, 为认识新生代东亚 季风变化驱动机制提供新证据.

\section{2 地理环境与样品采集}

渭河盆地位于中国黄土高原南缘和秦岭北麓，是 一个处于现代东亚季风降水影响边缘区域的断陷盆地 (图1). 新生代渭河盆地沉降, 秦岭山脉隆升, 构成一个 伸展构造环境下的山-盆系统(孟庆任, 2017). 从始新世 开始，渭河盆地接受了厚度超过 $7000 \mathrm{~m}$ 的较为连续的 河湖相沉积, 在 $7 \mathrm{Ma}$ 开始堆积同期异相的风成沉积. 因此, 渭河盆地可以看作是新生代亚洲季风降水的“雨 量筒”(鹿化暗等, 2018). 通过对岩性地层、生物地层 等分析，厘定了蓝田地区新生代地层序列，包括始新 世红河组, 渐新世白鹿塬组, 中新世冷水沟组、寇家 村组、灞河组，晚中新世-上新世蓝田组，更新世三门 组(与第四纪黄土古土壤为同期异相沉积)(贾兰坡等, 1966; 张玉萍等, 1978; Kaakinen和Lunkka, 2003; Kaakinen, 2005; Wang等, 2014; 孙文峰等, 2017; 鹿化暗等, 2018; Wang等, 2020). 本次研究选取各时代典型代表 剖面的泥质沉积层, 共138个样品用于黏土矿物 X射线 衍射分析(XRD). 其中, 始新世红河组样品 40 个, 渐新 世白鹿塬组样品 21 个, 中新世冷水沟组、寇家村组样 品 19 个, 灞河组样品 19 个, 晚中新世-上新世蓝田组样 品 23 个, 更新世三门组样品 8 个以及现代盆地河流冲积 物样品 8 个(图2).

如图2和图3, 研究剖面从老到新分别为红河组王 坪村剖面(WPC)、李家西坡剖面(LJXP), 白鹿塬组支 家沟剖面 $(\mathrm{ZJG})$, 冷水沟组、寇家村组疮㽽庙剖面 (GDM), 灞河组水吴村剖面(SWC), 蓝田组烡沟村剖面 (CGC), 三门组张家坡沟剖面(ZJPG). 上述剖面均为河 湖相沉积. 岩性描述如下:

(1) 王坪村(WPC)剖面厚度为 $313.5 \mathrm{~m}$. 岩性整体为 紫红色泥岩夹黄色、灰绿色砂岩, 见水平层理、韵律 层, 顶部 $100 \mathrm{~m}$ 砂岩逐渐增多, 泥岩中常见蓝绿色斑点 和条带, 呈网纹化特征, 指示了浅湖沉积环境. 底部 $19 \mathrm{~m}$ 是黄褐色砾石层(图4a, 4b), 夹少量薄层泥岩, 砾 石以石英岩和花岗岩为主, 粒径多为 $5 \sim 40 \mathrm{~cm}$, 磨圆差, 一般为棱角状、次棱角状, 风化严重, 可能为盆地发育 初期的山间冲积物. 其与上覆白鹿塬组平行不整合接 

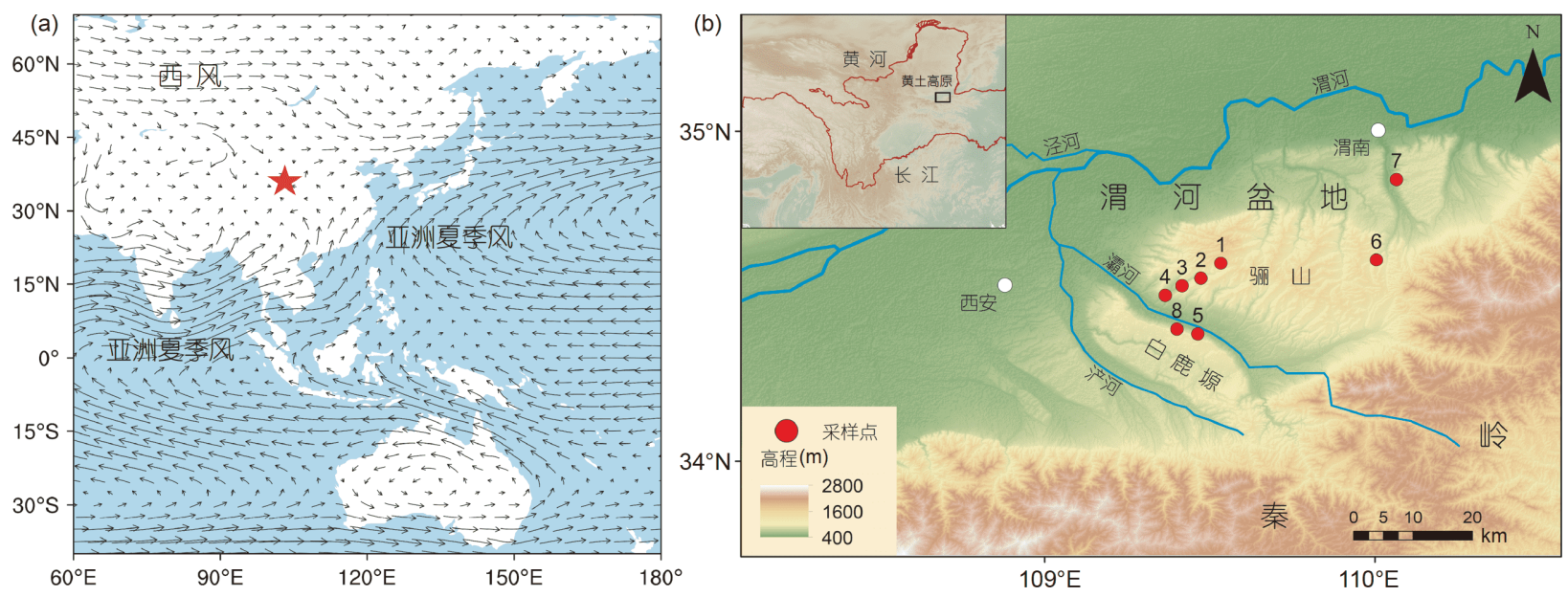

图 1 渭河盆地区域大气环流和地理位置

(a) 红色星号表示渭河盆地. 依据1979 2020年ERA5 850hPa 4 9月平均风场数据绘制. (b) 盆地地貌, 插图显示渭河盆地位于黄河流域中游. 1, 王坪村剖面(WPC); 2, 李家西坡剖面(LJXP); 3, 支家沟剖面(ZJG); 4, 疮㾂庙剖面(GDM); 5, 水吴村剖面(SWC); 6, 茬沟村剖面(CGC); 7, 张家坡 沟剖面(ZJPG); 8, 段家坡剖面(DJP)

触, 与下伏前震旦系基岩角度不整合接触.

(2) 李家西坡(LJXP)剖面厚度为 $40.7 \mathrm{~m}$. 岩性为紫 红色砂质泥岩, 顶部与支家沟剖面平行不整合接触, 可 能与王坪村剖面顶部有一定的重合. 本次研究暂时将 李家西坡剖面样品数据放于王坪村剖面和支家沟剖面 之间.

(3) 支家沟(ZJG)剖面厚度为 $361.4 \mathrm{~m}$. 岩性可分为 三部分：下部 $150 \mathrm{~m}$ 主体为灰白色砂岩、砂砾岩夹薄层 棕红色粉砂质泥岩, 见水平层理, 砂岩层巨厚且横向延 伸范围广，为滨湖相沉积; 中部 $180 \mathrm{~m}$ 为棕红色泥岩、 粉砂质泥岩与灰白色砂岩互层, 见水平层理, 浅湖相与 滨湖相交替, 代表湖泊进退的沉积旋回; 上部 $30 \mathrm{~m}$ 是一 套巨厚的灰白色砂岩, 夹薄层小砾石层, 为滨湖相沉积 (图 $4 \mathrm{c} ， 4 \mathrm{~d}$ ). 顶部与冷水沟组、寇家村组角度不整合 接触.

(4) 疮㾑庙(GDM)剖面厚度为79.3m. 岩性可分为 两部分: 下部 $40 \mathrm{~m}$ 主体为灰白色砾岩、砂砾岩, 夹数层 棕红色砂质泥岩，指示辡状河道沉积夹杂少量河漫滩 相、浅湖相沉积; 上部 $39 \mathrm{~m}$ 为棕黄色砂质泥岩与棕红 色粉砂质泥岩、泥岩互层, 见水平层理(图4e), 指示浅 湖沉积环境. 前人将下部划分为冷水沟组, 将上部划分 为寇家村组, 两组之间平行不整合接触, 寇家村组顶部 与上覆灞河组平行不整合接触.

(5) 水吴村(SWC)剖面厚度为 $182.8 \mathrm{~m}$. 岩性可分为 两部分：下部110m棕红色泥岩夹灰黄色砂层、砂质泥 岩; 上部 $70 \mathrm{~m}$ 为灰白色、淡黄色砂岩与棕红色砂质泥 岩互层, 夹薄层灰绿色泥岩. 指示辫状河道、洪水漫 滩、泛滥平原夹杂古土壤和湖相沉积. 最常见的沉积 组分为厚层横向延伸好的细粒沉积物, 由洪泛平原上 的悬移质沉降形成, 代表低能环境. 数米乃至数十公 分的砂岩、砾岩代表不断迁移的辫状河道(Kaakinen 和Lunkka, 2003). 顶部与上覆蓝田组不整合接触.

(6) 苌沟村(CGC)剖面厚度为 $268.5 \mathrm{~m}$. 岩性分为三 部分: 底部 $70 \mathrm{~m}$ 以棕红色泥岩、粉砂质泥岩为主, 夹数 层薄层灰白色砂岩、砂砾岩, 偶见薄层砾石层, 见水平 层理, 湖相韵律层, 其中泥岩层偶见铝结核、钙质斑点 和少量青灰色斑块, 指示了浅湖到滨湖的沉积环境; 中 部 $118 \mathrm{~m}$ 是棕红色块状砂质泥岩、泥岩和含砾砂岩、 砂岩、砾岩互层, 砾石次圆到圆, 分选较好, 多为 $5 \sim 10 \mathrm{~cm}$, 砂砾层多为颗粒支撑(图4f), 指示了河床、河 漫滩、浅湖交替出现的沉积环境; 上部 $80 \mathrm{~m}$ 棕红色块 状砂质泥岩(图 $4 \mathrm{~g}$ )与黄色含砾砂岩、砾岩互层, 砾石 层多颗粒支撑，少数基质支撑，指示了泛滥平原的沉 积环境, 砂砾层为水动力较大时的洪水沉积, 部分层 位出现较多青灰色斑块, 多成网纹状(图4h), 表明曾暴 露于地表. 该剖面上覆第四纪黄土古土壤序列, 与风成 红黏土为同期异相沉积.

(7) 张家坡沟 (ZJPG)剖面厚度为 $124.1 \mathrm{~m}$. 岩性分为 


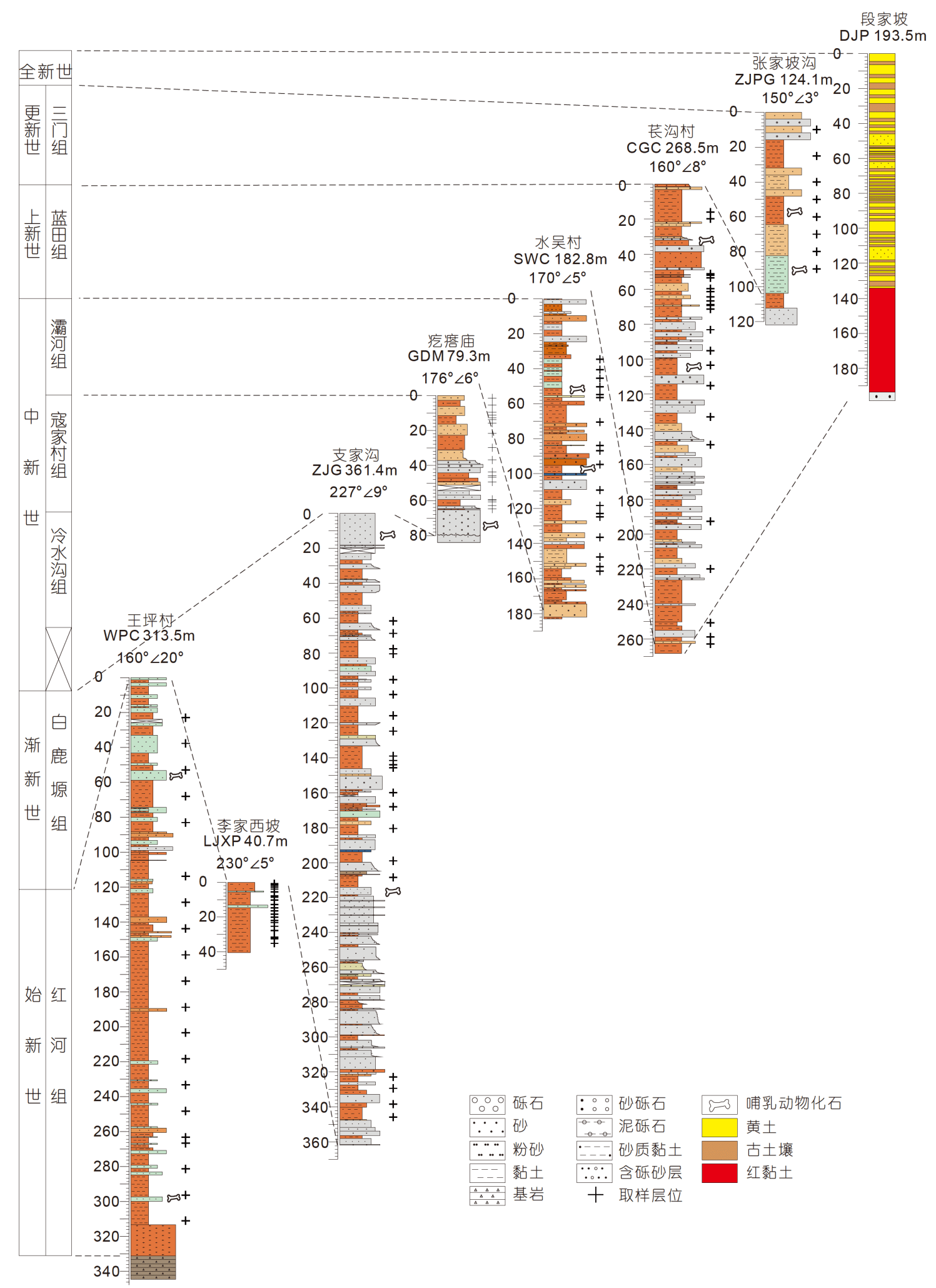

图 2 渭河盆地新生代沉积序列及采样层位

WPC、LJXP、ZJG、GDM、SWC、CGC为实测剖面; ZJPG剖面深度根据张玉萍等(1978)估计, DJP剖面修改自Zheng等(1992) 

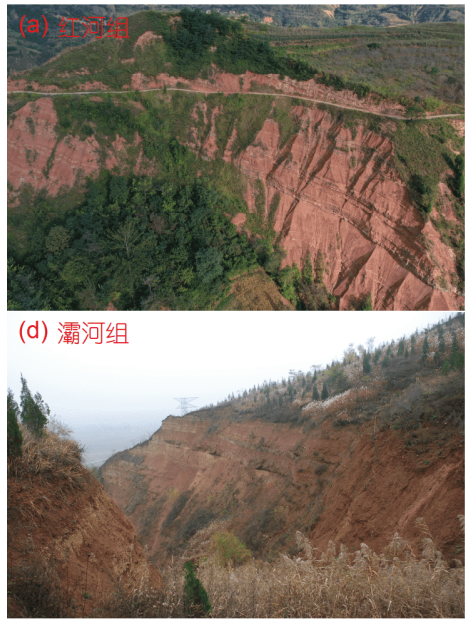

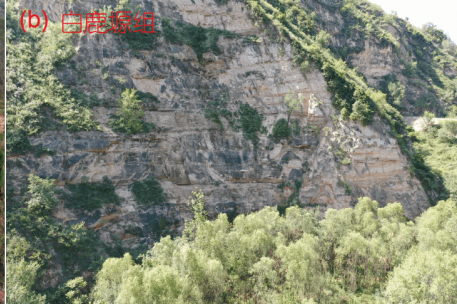

(e) 蓝田组 (c) 寇家村组

图 3 渭河盆地新生代沉积序列典型地层剖面

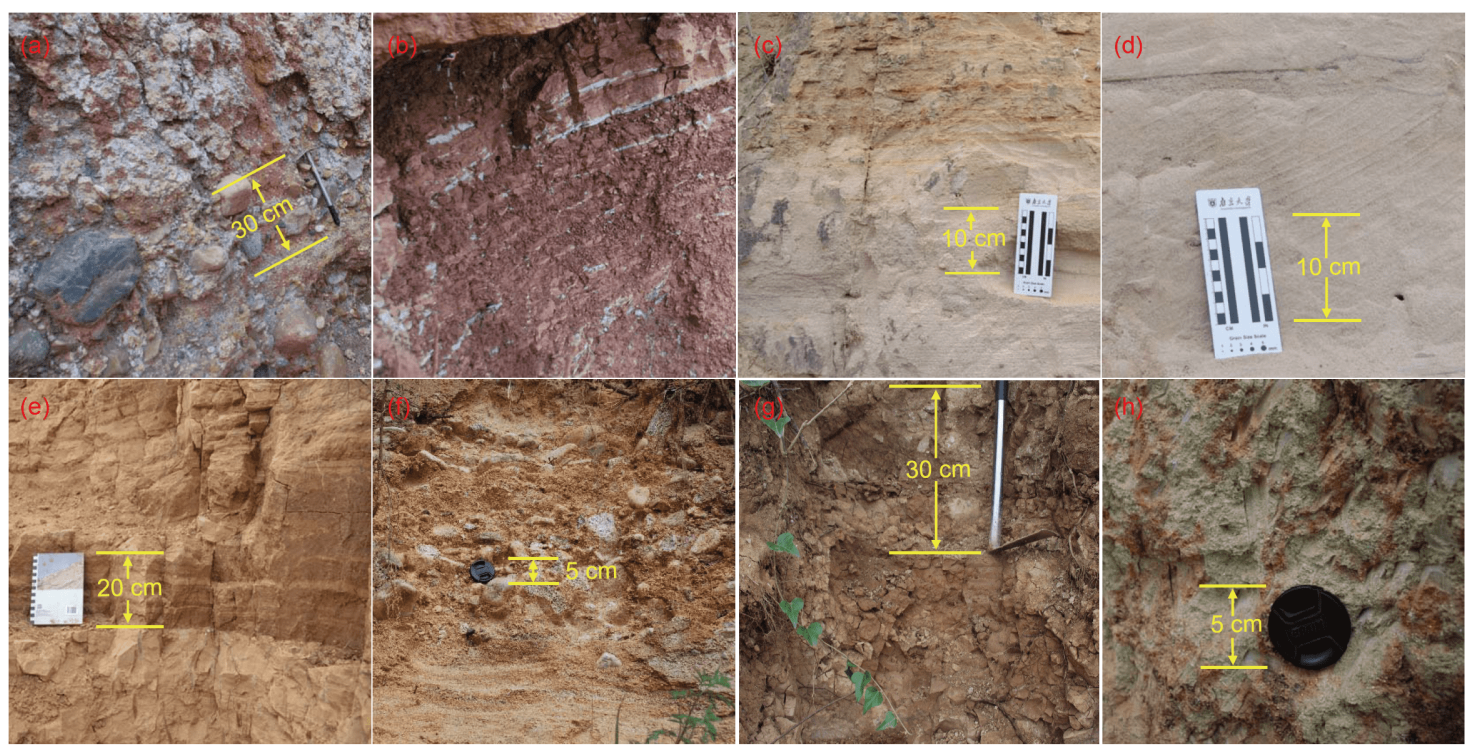

图 4 渭河盆地新生代沉积序列典型沉积相岩性

(a) 泥石流混杂堆积(王坪村剖面); (b) 水平层理浅湖相泥岩(王坪村剖面); (c) 水平层理滨湖相砂岩(支家沟剖面); (d) 斜层理滨湖相砂岩(支家 沟剖面); (e) 韵律层, 浅湖相泥岩(疮㾑庙剖面); (f) 河床砾石沉积(茬沟村剖面); (g) 块状结构, 洪泛平原沉积(芝沟村剖面); (h) 网纹化结构(莣沟 村剖面)

两部分：下部50m以灰绿色灰黄色粉砂、粉砂质泥岩 为主, 上部以棕黄色砂岩、灰白色砾石与棕红色粉砂 质泥岩互层, 均见水平层理, 为浅湖-滨湖沉积. 与第 四纪黄土古土壤为同期异相沉积.

上述剖面均为几乎连续的沉积序列, 但各剖面之 间可能存在一定的缺失. 各地层的时代框架根据动物 化石、岩性和磁性地层控制(鹿化暗等, 2018), 其中, 红河组王坪村剖面时代为45 33Ma(孙文峰等, 2017),
灞河组水吴村剖面时代为11 7Ma(Wang等，2014)，蓝 田组茬沟村剖面时代为6.73 2.58Ma(Wang等, 2020), 三门组为第四纪沉积(薛祥煦, 1981).

\section{3 测试方法}

\subsection{XRD分析}

黏土矿物测试在同济大学海洋地质国家重点实验 
室完成. 使用黏土粒级矿物 $(<2 \mu \mathrm{m})$ 定向薄片的 $X$ 射线 衍射法(X-ray Diffraction, XRD). 用 $10 \%$ 过氧化氢溶液 去除有机质、 $0.5 \%$ 盐酸溶液去除碳酸盐, 利用Stokes 沉降法则提取粘粒级组分. 上机测试使用PANalytical X'Pert PRO衍射仪, CuKa辐射, Ni滤波器, 管压 $45 \mathrm{kV}$, 管流 $40 \mathrm{~mA}$. 依次对自然条件、饱和乙二醇条件 (36h)、加热条件 $\left(490^{\circ} \mathrm{C}\right.$ 加热 $\left.2 \mathrm{~h}\right)(\mathrm{Liu}$ 等, 2016)预处理过 的样品薄片进行分析, 加热片只作鉴定黏土矿物使用 (部分样品加热多温度梯度 $200^{\circ} \mathrm{C} 、 300^{\circ} \mathrm{C} 、 490^{\circ} \mathrm{C}$ 便于 鉴定坡缕石以及高岭石、绿泥石的区分). 依据三种测 试条件下获得的XRD叠加波谱的综合对比分析, 鉴定 黏土矿物的组成, 然后使用MacDiff软件 $(R, 2000)$ 在乙 二醇饱和曲线上进行各矿物对应波峰参数的半定量计 算, 包括峰积分面积、半峰宽和峰强等. 主要分析四种 黏土矿物的相对含量: 蒙皇石、伊利石、高岭石和绿 泥石. 采用蒙皇石(包括伊蒙混层矿物)(001)15 17 ,

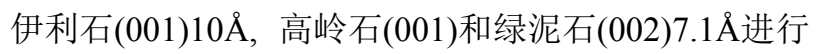
相对含量的计算, 其中, 高岭石和绿泥石的比例通过拟 合 $3.57 \AA / 3.54 \AA$ 峰面积比确定. 计算相对含量时, 选择 面积归一化法计算黏土矿物相对百分含量, 权重因子 为伊利石: 高岭石(绿泥石): 蒙脱石为 $4: 2: 1$ (Biscaye, 1965), 该方法误差为 $5 \%$ 左右. 此外, 所有样品均含有 石英 $(4.26 \AA)$, 部分样品还含有其他矿物: 坡缕石 $(10.4 \AA)$, 长石 $(3.25 \AA, 3.19 \AA)$. 计算公式如下:

$$
\begin{aligned}
& \mathrm{SUM}=4 * \operatorname{lll}(001)+2 *(\operatorname{Kao}(001)+\operatorname{Chl}(002)) \\
& + \text { Sme(001), } \\
& \text { Sme } \%=\operatorname{Sme}(001) / \mathrm{SUM}^{*} 100 \% \text {, } \\
& \mathrm{Ill} \%=4 * \mathrm{Ill}(001) / \mathrm{SUM}^{*} 100 \% \text {, } \\
& \mathrm{Chl} \%=2 *(\operatorname{Chl}(004) *(\operatorname{Kao}(001)+\operatorname{Chl}(002)) \\
& /(\operatorname{Kao}(002)+\operatorname{Chl}(004))) / \mathrm{SUM}^{*} 100 \%, \\
& \mathrm{Kao} \%=2 *(\operatorname{Kao}(002) *(\operatorname{Kao}(001)+\operatorname{Chl}(002)) \\
& /(\operatorname{Kao}(002)+\operatorname{Chl}(004))) / \text { SUM }^{*} 100 \%, \\
& \mathrm{Pal} \%=\operatorname{Pal}(110) /(\mathrm{SUM}+\operatorname{Pal}(110)) * 100 \% \text {, } \\
& \text { Ill Crysta }=\text { FWHM(Illite(001)), } \\
& \text { Ill Chem }=\operatorname{Ill}(002) / \operatorname{Ill}(001) \text {. }
\end{aligned}
$$

其中, SUM表示四种常见黏土矿物各特征晶面峰面积 乘上权重因子之和, Sme为蒙皇石, Ill为伊利石, Kao 为高岭石, $\mathrm{Chl}$ 为绿泥石, $\mathrm{Pal}$ 为坡缕石, $\mathrm{FWHM}$ 为半峰 宽, Ill Crysta为伊利石结晶度, Ill Chem为伊利石化学
指数. 伊蒙混层矿物中伊利石晶层相对含量依据Reynolds的方法估计(Reynolds，1980). 对于含有坡缕石 的样品, 考虑到拟合分峰的方式只能保证两峰相对面 积较为准确, 对实际半高宽可能产生一定的误差, 最 终选用 $10 \AA$ 峰右半峰宽度乘 2 的方式计算伊利石结 晶度.

全样非定向片在南京大学内生金属矿床成矿机制 研究国家重点实验室完成, 没有经过化学处理. 上机测 试使用Dmax IIIa衍射仪, CuKa辐射, 管压 $40 \mathrm{kV}$, 管流 $25 \mathrm{~mA}$.

\subsection{SEM和EDS分析}

选取块状样品, 表面喷铂导电处理后进行扫描电 镜(SEM)观察矿物形态. 在扫描电镜观察过程中, 所选 区域的元素相对含量由 $15 \mathrm{kV}$, 分辨率为 $0.8 \mathrm{~nm}$ 的 $X$ 射线 能谱(EDS)系统测定. SEM和EDS观测在南京大学表生 地球化学教育部重点实验室使用Sigma 500 场发射扫 描电镜完成.

\section{4 结果}

\section{1 全岩矿物组合和黏土矿物含量}

全样非定向片XRD结果表明(图5), 渭河盆地新生 代沉积序列全样中均包括石英、钾长石、斜长石、方 解石, 白云石含量较少或几乎没有, 少量以原白云石 为主.

黏土定向片XRD测试表明(图6), 渭河盆地新生代 沉积序列样品中黏土矿物均包含蒙皇石(含伊蒙混层 矿物 $(\mathrm{I} / \mathrm{S}))$ 、伊利石、绿泥石、高岭石及少量石英和 长石, 红河组、白鹿塬组、冷水沟组、寇家村组部分 样品包含坡缕石. 其中, 坡缕石是纤维性的, 不能在定 向片中生成晶面优势性的衍射图. 因为大多数衍射面 的峰强度较弱, 所以只有样品中含量较高时才能观察 到. 依据乙二醇图谱中 $10.4 \AA$ 和 $6.4 \AA$ 的峰鉴定坡缕石, 根据其不会在乙二醇饱和过程中发生膨胀, 且在加热 温度小于 $200^{\circ} \mathrm{C}$ 时不会影响衍射图谱, 随着温度进一 步升高衍射峰逐渐转移的特性, 来区别低角度区的其 他混层和膨胀性的黏土矿物(李艳丽, 未发表的成果) (图6). 其中, 蒙皇石是含量最高的黏土矿物, 伊利石次 之(表1).

砾石层和中粗砂层可能是摆动的辫状河道沉积, 


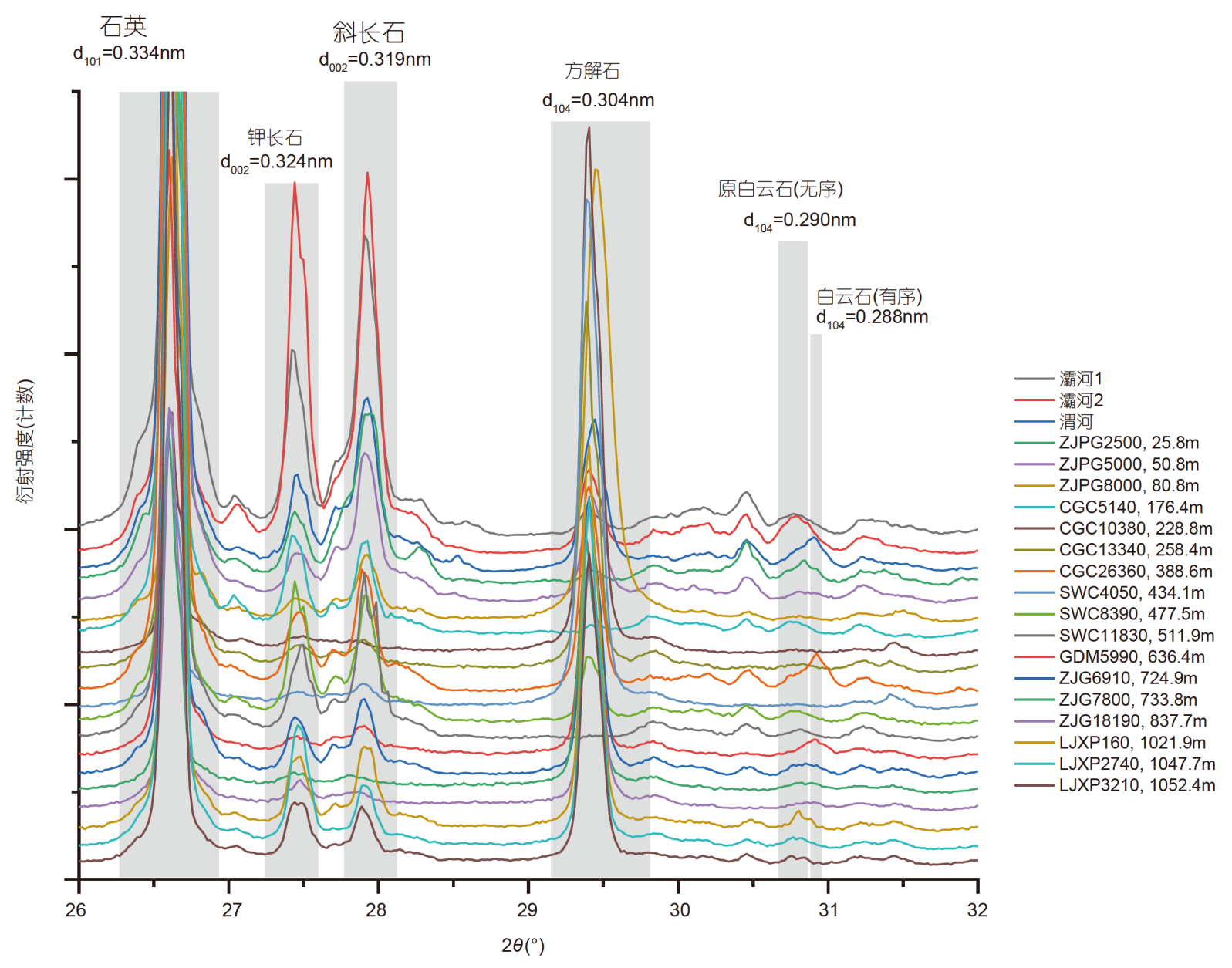

图 5 渭河盆地新生代沉积各地层组典型层位全样非定向片XRD分析谱

与同期的湖相沉积非同一沉积环境，并不能准确提供 气候信息. 因此本研究为避免不同岩性和不同沉积相 的影响, 尽量选择颗粒较细近湖相的层位(包括泥岩、 砂质泥岩、粉砂、细砂), 其中泥岩样品56块, 砂质泥 岩样品 50 块, 粉砂样品 18 块, 细砂样品 14 块. 如图7和表 1 , 各岩性之间黏土矿物相对含量并无明显差异.

绿泥石和高岭石含量始终较低, 除少数样品外, 均 在 $10 \%$ 以下. 黏土矿物含量变化主要以蒙皇石为主, 伊 利石变化趋势与蒙皇石相反. 红河组蒙皇石含量较为 稳定, 约为 $50 \%$. 在白鹿塬组蒙皇石含量从 $50 \%$ 上升至 $70 \%$, 伊利石含量从 $40 \%$ 下降至 $20 \%$; 冷水沟组、寇家 村组、灞河组蒙皇石含量从 $89 \%$ 到 $16 \%$ 波动性较大. 蓝田组以来蒙皇石含量从 $86 \%$ 到 $8 \%$ 波动性下降至今. 在红河组晚期、白鹿塬组及寇家村组、冷水沟组坡缕 石出现, 约为 $3 \%$, 而在后期各组中消失(图 8 ). 伊利石结
晶度在红河组早期较低, 约为 0.34 , 随后升高至 0.49 , 从 红河组中期开始从 0.49 阶段性下降至 0.25 . 伊利石化学 指数在红河组从 0.56 逐渐下降至 0.26 , 红河组晚期略有 回升, 随后在各组间波动, 约为 0.37 (图9).

\section{2 扫描电镜形貌}

如图10a和 $10 \mathrm{~b}$, 碎屑矿物颗粒零星散布在沉积物 中, 片状及丝状黏土矿物充填在碎屑矿物孔隙或附着 在其表面. 碎屑矿物边缘呈棱角状, 反映其经过距离 较短的搬运和沉积过程. 伊利石、绿泥石等片状黏土 矿物多发育不规则、残缺的边缘或呈卷曲状, 具有典 型碎屑成因特征. 坡缕石呈毛发状、纤维状和针状、 细棒状, 晶粒长一般为 $3 \sim 5 \mu \mathrm{m}$, 宽为 $0.05 \sim 0.3 \mu \mathrm{m}$. 如图 $10 \mathrm{c} 、 10 \mathrm{~d}$ ，毛发状、短棒状坡缕石有时可见沿片状黏 土矿物颗粒的边缘交代生长，不同颗粒相互缠绕呈交 

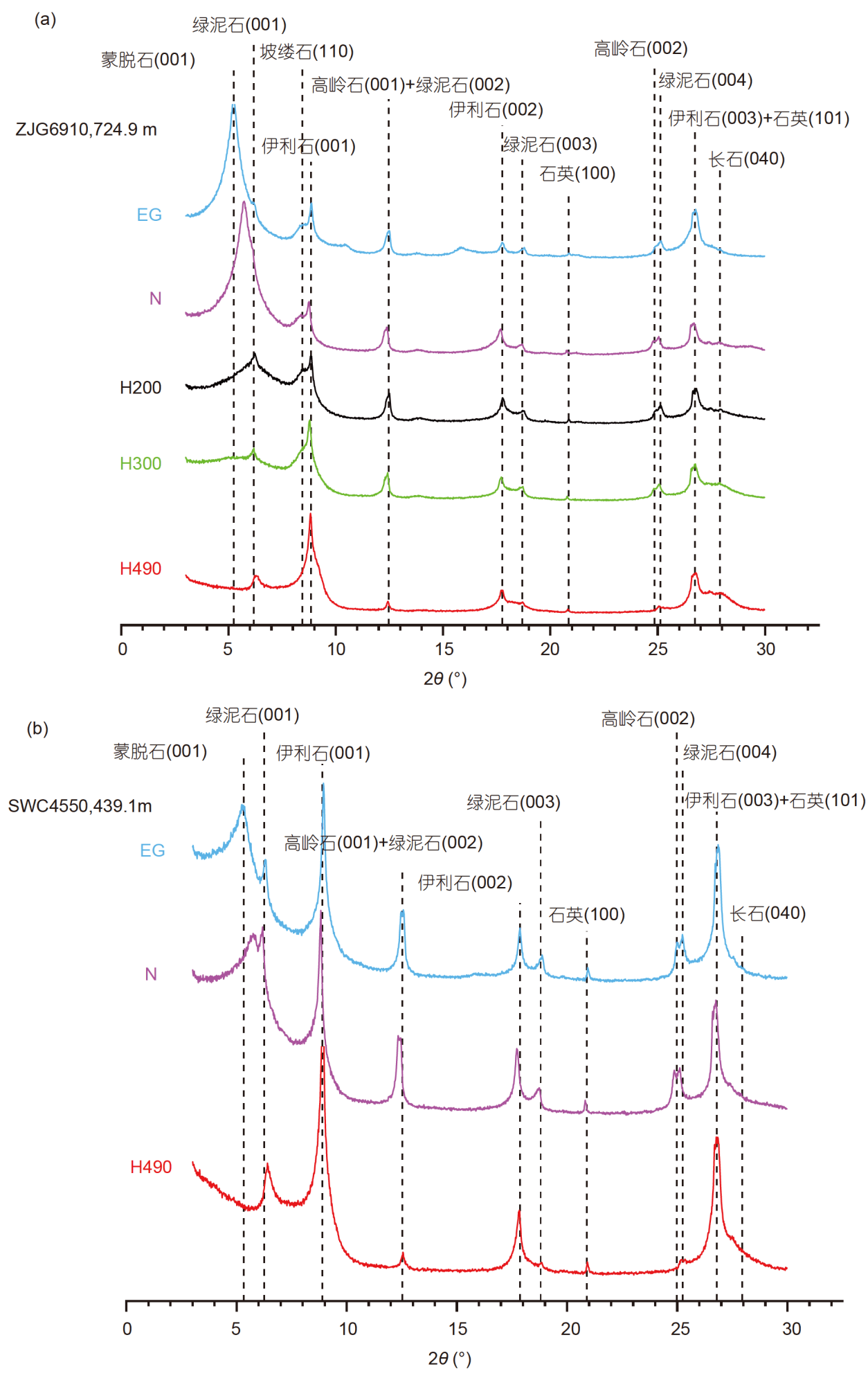

图 6 不同前处理方法提取的黏土矿物样品定向片XRD分析谱

(a) 含坡缕石样品; (b) 不含坡缕石样品. ZJG6910,724.9m含义为该样品来自白鹿塬组支家沟剖面69.1m处, 对应总深度为724.9m; SWC4550, $439.1 \mathrm{~m}$ 含义为该样品来自灞河组水吴村剖面 $45.5 \mathrm{~m}$ 处, 对应总深度为 $439.1 \mathrm{~m}$, 以此类推; $\mathrm{N}$, 自然原片样品; EG, 乙二醇饱和样品; H200、 $\mathrm{H} 300 、 \mathrm{H} 490,200^{\circ} \mathrm{C} 、 300^{\circ} \mathrm{C} 、 490^{\circ} \mathrm{C}$ 加热样品 
表 1 渭河盆地红河组-三门组各地层样品不同岩性黏土矿物相对含量

\begin{tabular}{|c|c|c|c|c|c|c|}
\hline 岩性 & & 全部 & 泥岩 & 砂质泥岩 & 粉砂 & 砂岩 \\
\hline 样品数 & & 138 & 56 & 50 & 18 & 14 \\
\hline 蒙㿝石(\%) & $\begin{array}{c}\text { 范围 } \\
\text { 平均值 }\end{array}$ & $\begin{array}{c}7.7 \sim 89.4 \\
52.3\end{array}$ & $\begin{array}{c}16.0 \sim 83.4 \\
52.9\end{array}$ & $\begin{array}{c}19.4 \sim 85.6 \\
51.7\end{array}$ & $\begin{array}{c}11.9 \sim 89.4 \\
51.7\end{array}$ & $\begin{array}{c}7.7 \sim 84.4 \\
52.3\end{array}$ \\
\hline 伊利石(\%) & $\begin{array}{c}\text { 范围 } \\
\text { 平均值 }\end{array}$ & $\begin{array}{c}7.8 \sim 77.1 \\
39.1\end{array}$ & $\begin{array}{c}14.3 \sim 71.1 \\
39.1\end{array}$ & $\begin{array}{c}11.2 \sim 63.6 \\
39.6\end{array}$ & $\begin{array}{c}7.8 \sim 62.4 \\
38.9\end{array}$ & $\begin{array}{c}9.5 \sim 77.1 \\
37.7\end{array}$ \\
\hline 绿泥石(\%) & $\begin{array}{c}\text { 范围 } \\
\text { 平均值 }\end{array}$ & $\begin{array}{c}0.6 \sim 25.0 \\
4.5\end{array}$ & $\begin{array}{c}0.7 \sim 11.9 \\
4.4\end{array}$ & $\begin{array}{c}0.6 \sim 11.0 \\
4.0\end{array}$ & $\begin{array}{c}1.4 \sim 17.1 \\
5.6\end{array}$ & $\begin{array}{c}1.4 \sim 25.0 \\
5.7\end{array}$ \\
\hline 高岭石(\%) & $\begin{array}{l}\text { 范围 } \\
\text { 平均值 }\end{array}$ & $\begin{array}{c}0.8 \sim 14.9 \\
4.1\end{array}$ & $\begin{array}{c}0.8 \sim 9.8 \\
3.5\end{array}$ & $\begin{array}{c}1.0 \sim 14.9 \\
4.7\end{array}$ & $\begin{array}{c}1.4 \sim 8.6 \\
3.9\end{array}$ & $\begin{array}{c}1.5 \sim 7.1 \\
4.3\end{array}$ \\
\hline
\end{tabular}

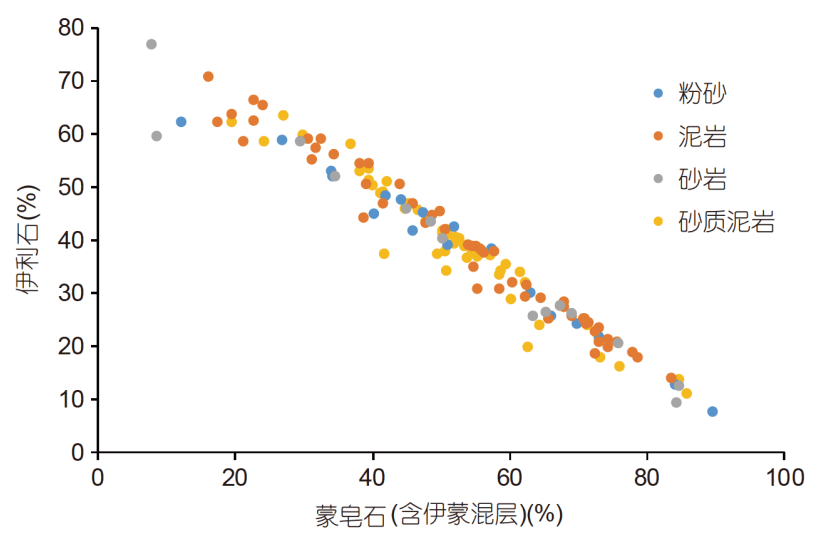

图 7 各剖面湖相地层中不同岩性蒙皇石(含伊蒙混层)与 伊利石相对含量分布

织状特征, 表明其自生成因. 能谱分析结果表明坡缕石 矿物富含 $\mathrm{Si} 、 \mathrm{O} 、 \mathrm{Al} 、 \mathrm{Fe} 、 \mathrm{Mg}$ ，有的含有一定量的 $\mathrm{K}$ 和 $\mathrm{Ca}$, 可能与样品中的伊利石和碳酸盐有关. 如图 $10 \mathrm{e}$, 片状黏土矿物富含 $\mathrm{Si} 、 \mathrm{O} 、 \mathrm{Al} 、 \mathrm{Fe} 、 \mathrm{Mg} 、 \mathrm{Ca}$ ，同时含 有一定的 $\mathrm{K}$, 可能为伊蒙混层; 图10f中坡缕石附着的 片状黏土具有典型的“蜂窝状”结构, 结合能谱表明其 含有一定的 $\mathrm{Ca} 、 \mathrm{Na}$ ，即前驱矿物为蒙脱石．同时，图 $10 \mathrm{~b}$ 中蒙脱石矿物表面同样存在较密集的坡缕石纤维. 因此，成岩成因的坡缕石其前驱矿物为蒙脱石或伊蒙 混层.

\section{5 讨论}

\section{1 渭河盆地沉积物黏土矿物的形成环境及其指 示意义}

在表生风化成壤条件下，黏土矿物的形成与演化 往往与气候条件密切相关, 黏土矿物的组合类型呈现
出明显的地带性分布规律. 因此，根据黏土矿物的组 合类型及其特征晶体结构参数可以判断沉积物形成时 的气候环境(Singer, 1980; Chamley, 1989; 季峻峰等, 1997; Wang等, 2017; Song等, 2018; Liu等, 2020). 然而, 对于河湖相沉积，复杂的物源变化、水动力带来的粒 径分选及凝絮作用，搬运沉积过程中自生黏土矿物的 形成以及成岩作用也会对黏土矿物含量及其特征造成 较大的影响. 本文将从以下几个方面进行分析.

(1) 物源. 构造运动可能是导致盆地河湖相沉积物 物源变化的潜在因素. 始新世以来渭河盆地沉积物是 来自周缘山地剥蚀的产物, 从红河组到三门组的数千 米沉积序列中均存在粉砂-砂-砾石层的旋回, 表明始 新世以来构造尺度上渭河盆地河湖沉积体系没有明显 的变化(李智超等, 2015; 鹿化显等, 2018). 我们的采样 点位于渭河盆地的南缘, 紧邻北秦岭. 北秦岭自始新世 以来经历了两次主要的抬升剥蚀阶段: $50 \mathrm{Ma}$ 以来缓 慢地剥露, $\sim 10 \mathrm{Ma}$ 开始快速地剥露抬升, 持续至第四 纪(Liu等, 2013). 与此同时, 渭河盆地也大幅度沉降. 新生代秦岭山脉与渭河盆地构成了较为稳定的伸展构 造环境下的山-盆体系(孟庆任, 2017). Sr-Nd同位素数 据表明, 渭河盆地河湖相沉积物的 $\mathrm{Nd}$ 同位素 $\varepsilon_{\mathrm{Nd}}(0)$ 绝 大多数分布于 $-10 \sim-12$, 其分布完全落在北秦岭不同 岩体的Sr-Nd同位素分布范围之内(雷昉等, 未发表的 数据). 因此, 可推断渭河盆地蓝田地区新生代以来沉 积物主要来自于北秦岭.

北秦岭岩性复杂, 包括秦岭群角闪岩相变质岩, 二 郎坪群、丹凤群蛇绿岩、火山-沉积岩, 宽坪群绿片 岩、角闪岩、变质碎屑岩, 刘岭群浅变质沉积岩系等 (王晓霞等, 2015), 另外, 还出露印支期和燕山期花岗 岩(张国伟等, 2001). 盆地边缘沉积物是花岗岩、变质 


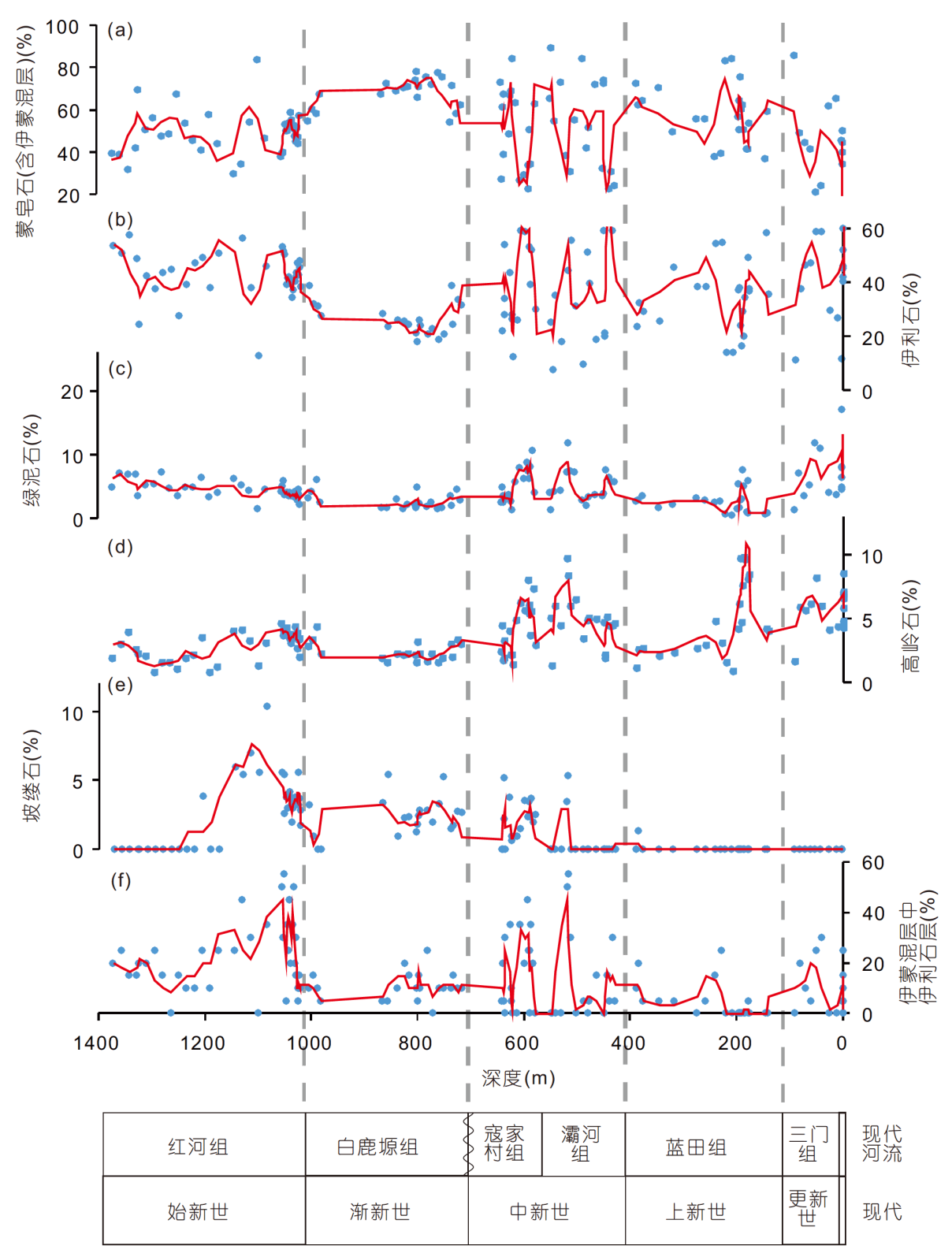

图 8 渭河盆地新生代河湖相沉积物黏土矿物相对含量变化

红色拟合线为三点平滑结果

岩、沉积岩等的混杂堆积. 各时期泥质层位薄片显微 照片显示均为石英、长石等粗颗粒矿物与黏土矿物、 碳酸盐等细颗粒矿物的集合体(图11), 全样XRD的结 果同样表明矿物组合并未发生明显的变化(图5), 因此, 不考虑物源的变化导致黏土矿物形成的差异. 当黏土 矿物组合发生明显变化, 比如由蒙皇石为主转变为伊 利石为主，应当谨慎考虑此过程的气候意义，很有可 能是由于构造的剧烈运动导致物理剥蚀加剧, 使得黏
土矿物的组合发生转变. 因此, 利用黏土矿物解释古 气候时，整个风化剖面中黏土矿物组合保持一致极为 重要(Singer, 1980). 渭河盆地均以蒙皇石、伊利石为 主, 矿物组合未发生明显转变, 是其能用以判断气候的 前提条件.

(2) 粒径分选及凝絮作用. 不同粒径的沉积物可能 经过沉积分选而重新分布. 高岭石颗粒较大, 粒径一般 在0.5 8 $\mu \mathrm{m}$, 而蒙皇石粒径较小, 通常小于 $1 \mu \mathrm{m}$. 搬运过 

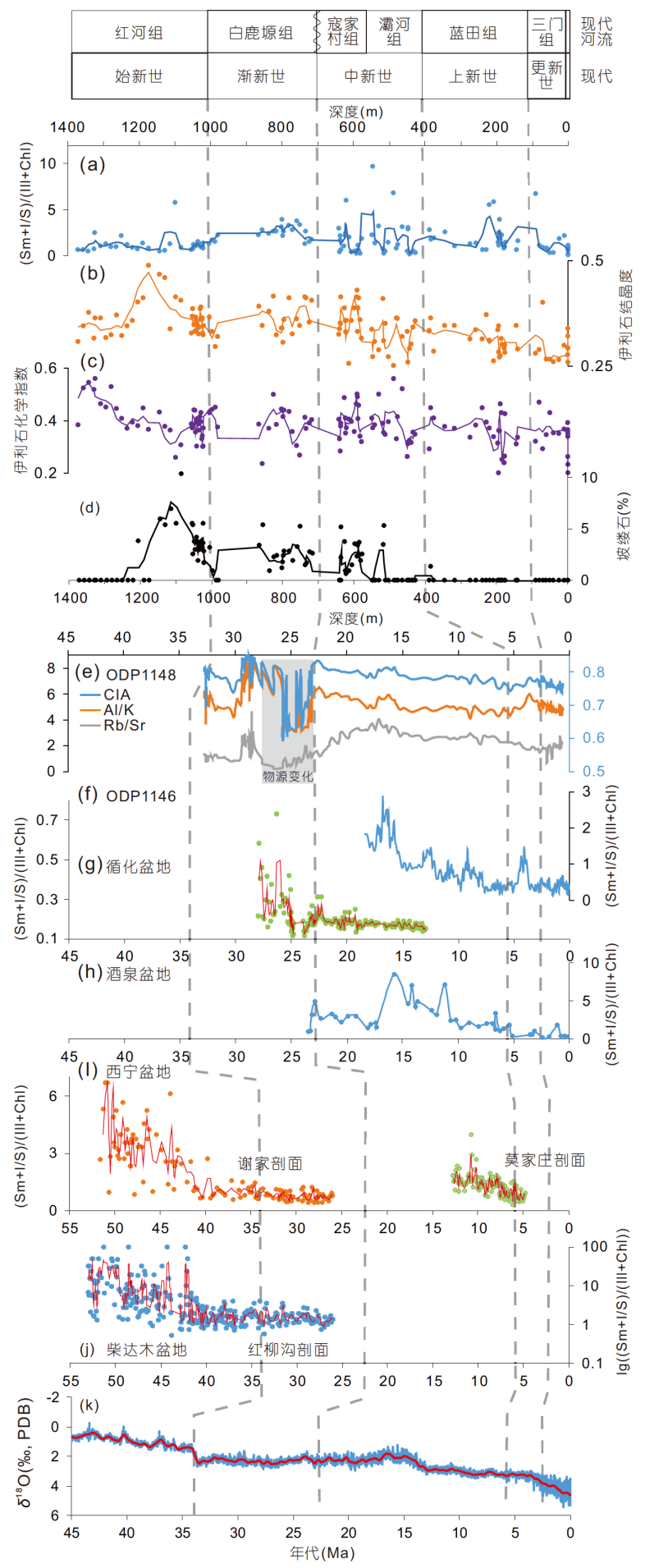

图 9 渭河盆地黏土矿物及其与其他海-陆记录的对比

(a) 渭河盆地黏土矿物比值 $(\mathrm{Sm}+\mathrm{I} / \mathrm{S}) /(\mathrm{III}+\mathrm{Chl})$; (b) 伊利石结晶度; (c) 伊利石化学指数; (d) 坡缕石相对含量; (e) 南海ODP1148钻孔化学风化指 标; (f) 南海ODP1146钻孔黏土比值 $(\mathrm{Sm}+\mathrm{I} / \mathrm{S}) /(\mathrm{Ill}+\mathrm{Chl}) ;(\mathrm{g})$ 循化盆地黏土比值 $(\mathrm{Sm}+\mathrm{I} / \mathrm{S}) /(\mathrm{Ill}+\mathrm{Chl}) ;(\mathrm{h})$ 酒泉盆地黏土比值 $(\mathrm{Sm}+\mathrm{I} / \mathrm{S}) /(\mathrm{Ill}+\mathrm{Chl}) ;(\mathrm{i})$ 西 宁盆地黏土比值 $(\mathrm{Sm}+\mathrm{I} / \mathrm{S}) /(\mathrm{IIl}+\mathrm{Chl}) ;(\mathrm{j})$ 柴达木盆地黏土比值 $(\mathrm{Sm}+\mathrm{I} / \mathrm{S}) /(\mathrm{Ill}+\mathrm{Chl}) ;(\mathrm{k})$ 深海氧同位素记录. Sm蒙㿝石, I/S伊蒙混层, Ill伊利石, Chl 绿泥石. (a) (d)为本文数据; (e)引自L等(2003)、Wei等(2006); (f)引自Wan等(2007); (g)引自Liu等(2019); (h)引自Liu等(2020); (i)引自Fang等 (2019)、Yang等(2019); (j)引自Fang等(2019); (k)引自Westerhold等(2020) 


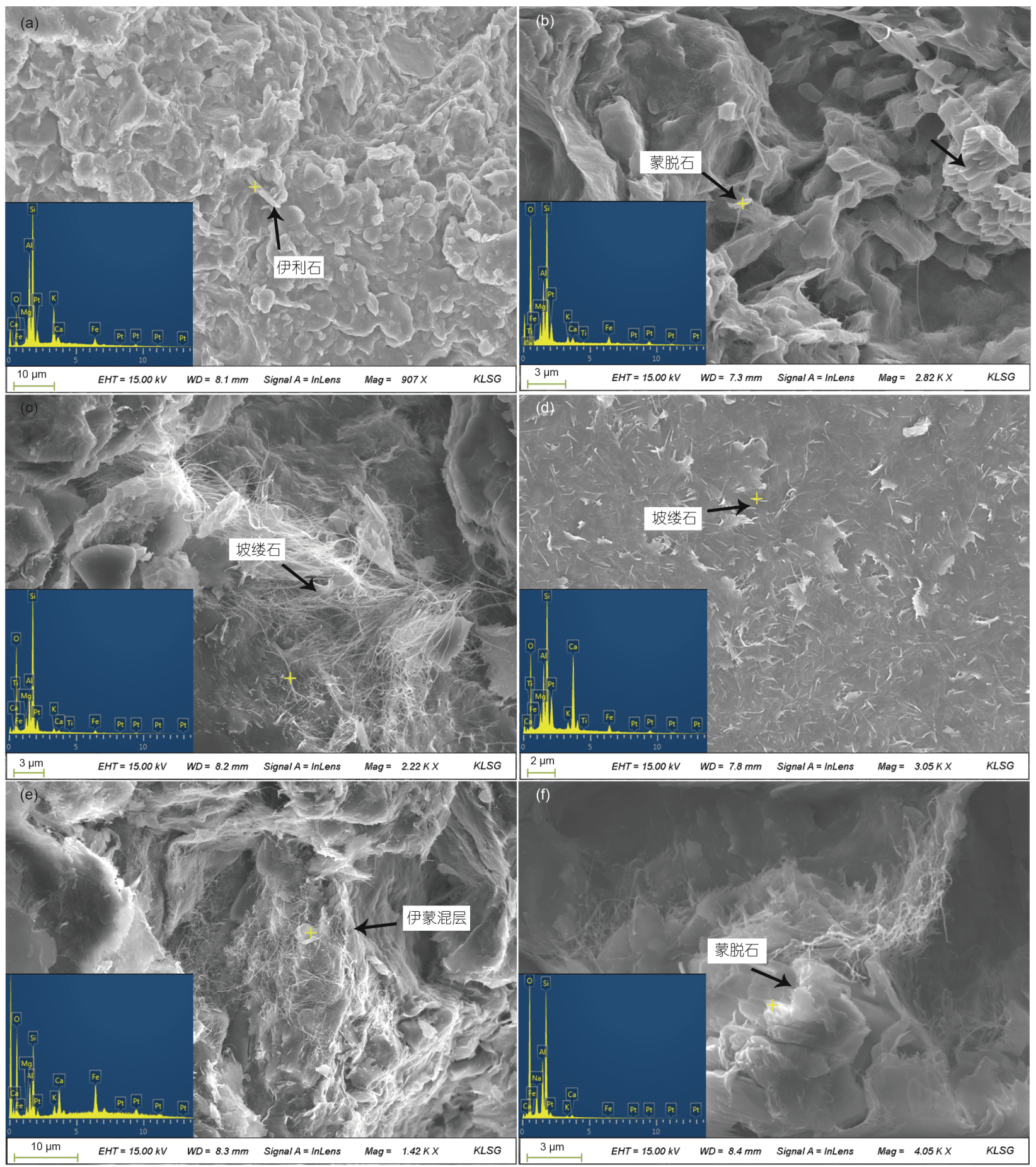

图 10 沉积物样品SEM和EDS显微形貌

(a) 碎屑矿物呈散状分布; (b) 丝状及片状黏土矿物在碎屑矿物中充填; (c) 毛发状坡缕石呈交织状; (d) 细棒状坡缕石; (e) 毛发状坡缕石附着于 伊蒙混层; (f) 毛发状坡缕石附着于蒙脱石

程中较大的高岭石可能比蒙皇石沉降更快, 因此蒙皇 石可能在更远端的水体中富集(Chamley，1989). 渭河
盆地河湖相沉积物黏土矿物以蒙皇石为主, 高岭石含 量较少, 且周边山地侵蚀产物呈现近距离搬运的特点 


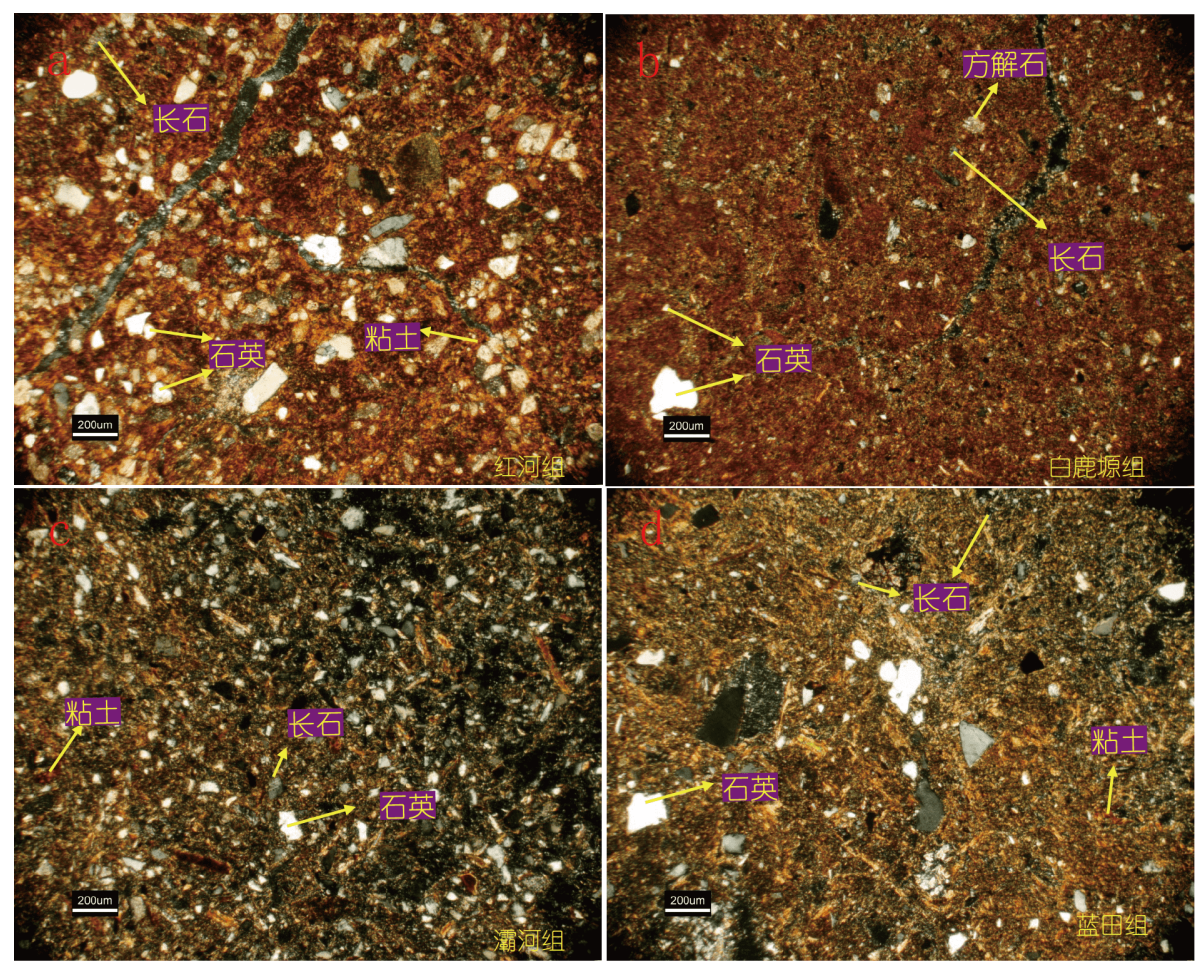

图 11 渭河盆地部分剖面泥质层位显微照片

(鹿化显等, 2018; Wang等, 2020), 因此, 暂不考虑黏土 矿物含量的相对变化是高岭石和蒙㿝石长距离搬运差 异沉降的结果.

(3) 成岩作用. 成岩作用是影响沉积岩中黏土矿物 类型的重要因素，蒙皇石伊利石化是沉积盆地十分普 遍的一种成岩过程(Chamley，1989). 随着成岩作用的 加强，伊蒙混层中蒙脱石晶层会随着深度的增加而降 低，与此同时，伊利石和绿泥石含量会随着深度的增 加而增加(Weaver，1989). 在沉积地层的成岩过程中, 通常分为两个阶段：一是伊蒙混层中伊利石层含量较 低时，伊利石层开始明显增加，表明伊利石化作用开 始; 二是有序化界线，不规则混层伊利石-蒙脱石转变 为规则混层伊利石-蒙脱石(Reynolds，1980；黄思静， 1990). 如图8, 渭河盆地新生代河湖相沉积黏土中混层 矿物均为不规则伊蒙混层，伊蒙混层中伊利石晶层含 量普遍较低，同时随着深度增加，含量并未明显持续 增加，可能表明尚未处于明显的成岩阶段．值得注意 的是，渭河盆地河湖相沉积物在红河组晚期、白鹿塬 组、寇家村组均出现坡缕石，其他各组消失. 而坡缕 石一般是干旱、半干旱地区泥灰岩风化及沙漠沉积物 的特征矿物，在偏碱性 $(\mathrm{pH}=8 \sim 9)$ 的环境和蒸发大于降
水条件下，更有利于坡缕石的形成和保存(Velde和 Meunier, 2008). 不同形态坡缕石对应有不同的古环境 意义, 针状、细棒状的坡缕石为区域化学风化的产物, 是代表着一种干旱、半干旱的区域环境(Singer和Galan, 2011), 而毛发状、纤维状的坡缕石在陆相河流湖 泊中很有可能是成岩作用的产物. 渭河盆地沉积物中 的坡缕石主要呈毛发状、纤维状, 细棒状较少, 明显 可见其交代蒙皇石边缘及表面，表明大部分坡缕石为 自生成因(图10). 同时，所有出现坡缕石的层位，伊蒙 混层矿物中伊利石层相对比例均较高(图8), 因此可能 存在较弱的早期成岩作用, 导致坡缕石的形成.

（4）黏土矿物的气候意义. 对现代陆相盆地黏土矿 物研究表明, 河湖相沉积物中的黏土矿物具有与周边 流域的相似特征. 河流和盐湖中阳离子的缺乏导致很 难形成自生黏土矿物(Chamley, 1989). 目前, 渭河流域 现代河流样品 8 个, 包括浐河样品 1 个, 灞河样品 6 个, 渭 河样品 1 个, 其中 5 个样品蒙皇石相对含量为 $34 \sim 50 \%$, 表明现代渭河流域黏土矿物仍然以蒙皇石和伊利石为 主. 但因现代样品数量较少，可能不具有足够的代表 性，未来可能需要更多的关于渭河流域现代河流、湖 泊、以及表土的黏土矿物研究. 晚新生代以来流域的 
内风尘物质主要包括风成红黏土、黄土古土壤沉积, 前人的研究表明黄土高原风成沉积以伊利石为主，蒙 皇石相对含量较低(3\%左右)(Gylesjö和Arnold，2006), 与本次研究差异较大. 结合上述对于各剖面的沉积学 描述, 及典型沉积相岩性分析, 本次研究的河湖相沉 积黏土, 可能受到风尘输入的影响较小. 因此, 渭河盆 地河湖相沉积物中黏土矿物可能反映流域范围内母岩 及风化壳的特征，可以用来指示新生代以来渭河流域 风化强度.

伊利石和其他云母矿物一般继承自母岩, 很难通 过成壤作用形成. 前人依据伊利石结晶度划分成岩带, 近变质带和浅变质带: $\mathrm{IC}<0.25^{\circ} \Delta 2 \theta$ 为浅变质带, $0.25^{\circ}$ $\Delta 2 \theta<\mathrm{IC}<0.42^{\circ} \Delta 2 \theta$ 为近变质带, $\mathrm{IC}>0.42^{\circ} \Delta 2 \theta$ 为成岩带 (Weaver, 1989). 渭河盆地河湖相沉积物中伊利石结晶 度值 $\left(0.23^{\circ} \sim 0.50^{\circ} \Delta 2 \theta\right)$ 大部分落在近变质带内, 极少数 位于浅变质带和成岩带范围内. 伊利石的结晶度实质 是反映伊利石的晶畴大小和结构膨胀程度(季峻峰等, 1997). 渭河盆地河湖相沉积物中伊利石经历了三个阶 段: 首先, 古老母岩中的伊利石可能在近变质或者类似 中高温的地质环境下形成，这种情况下形成的伊利石 晶型较好, 即伊利石结晶度值较低; 随后, 随着母岩在 新生代的暴露剥蚀环境下经历了化学风化的进一步改 造，在此过程中伴随离子的淋失，其结构中形成膨胀 层, 伊利石的退变使得伊利石结晶度值升高; 最后, 渭 河流域风化改造后的伊利石经过搬运、沉积汇聚于渭 河盆地. 因此, 在渭河盆地物源较为稳定和沉积后成岩 作用较弱的前提下，可用伊利石结晶度和伊利石化学 指数来重建区域古气候.

在含有混层矿物时，伊利石结晶度通常反映其含 有膨胀层的多少. 膨胀层的形成通常由三部分因素导 致: (1) 随风化淋溶程度的增大, 伊利石结构中形成膨 胀层而逐渐退变, 经伊利石-蒙脱石等混层矿物最终导 致蒙皇石的形成; (2) 阳离子交换作用的中间产物; (3)
成岩作用使得蒙脱石经伊蒙混层矿物向伊利石逆向转 变. 渭河盆地新生代河湖相沉积物中混层矿物的形成 包括伊利石的风化和蒙皇石的伊利石化两个过程. 即 使通过伊蒙混层的伊利石晶层随深度的变化认为剖面 成岩作用较弱，但仍难以定量区分风化过程和成岩过 程形成的混层矿物对于伊利石结晶度的贡献. 因此, 为消除较弱成岩作用导致混层矿物的形成从而影响伊 利石结晶度气候意义的判别, 即含有弱成岩成因坡缕 石的大部分样品伊利石结晶度值较大，将含有坡缕石 样品剔除后发现伊利石结晶度值阶段性下降趋势同样 较为明显(图12).

伊利石化学指数实质是富 $\mathrm{Fe}-\mathrm{Mg}$ 伊利石和富 $\mathrm{Al}$ 伊 利石相对含量的体现. 由于 $\mathrm{Mg}$ 的衍射能力较弱, 所以 伊利石 $\mathrm{Mg}$ 含量的减少会导致伊利石奇数峰 $(001$ 、 003、005衍射峰)相比于偶数峰( $002 、 004$ 衍射峰) 减 弱，前人根据伊利石化学指数划分伊利石种类：Ill $(002) / \mathrm{Ill}(001)<0.15$ 表明为富Fe-Mg伊利石(黑云母), Ill $(002) / \mathrm{Ill}(001)>0.5$ 为富 $\mathrm{Al}$ 伊利石(白云母)(Frey，1970). 因此, 伊利石化学指数越大, 表明更为活泼的 $\mathrm{Fe} 、 \mathrm{Mg}$ 元素淋失相对更多, 指示更为强烈的化学风化作用.

绿泥石是土壤和风化壳中的一种继承性黏土矿 物, 易于风化, 因此伊利石和绿泥石主控的黏土矿物组 合指示较强的物理风化过程，是较弱的水解作用以及 在寒冷和干旱气候条件下直接岩石剥蚀的产物(Liu等, 2016). 高岭石和三水铝石是在温暖湿润的条件下母岩 经历强烈的化学风化，金属离子不断淋滤被带走而形 成的最终产物(Chamley，1989)，土壤高岭石的形成需 要两个条件: (1) 亚热带和热带森林气候带, 年均温 $15 \sim 20^{\circ} \mathrm{C}$, 年降雨可能大于 $1000 \mathrm{~mm}$ 的偏酸性气候环境; (2) 排水条件较好, 有利于 $\mathrm{K}^{+} 、 \mathrm{Na}^{+}$等阳离子和 $\mathrm{SiO}_{2}$ 的 持久淋滤去除.

蒙㿝石矿物一般有两种成因: (1) 火山灰和玻璃质 凝灰岩蚀变或风化形成蒙脱石，只要有充足的水供给

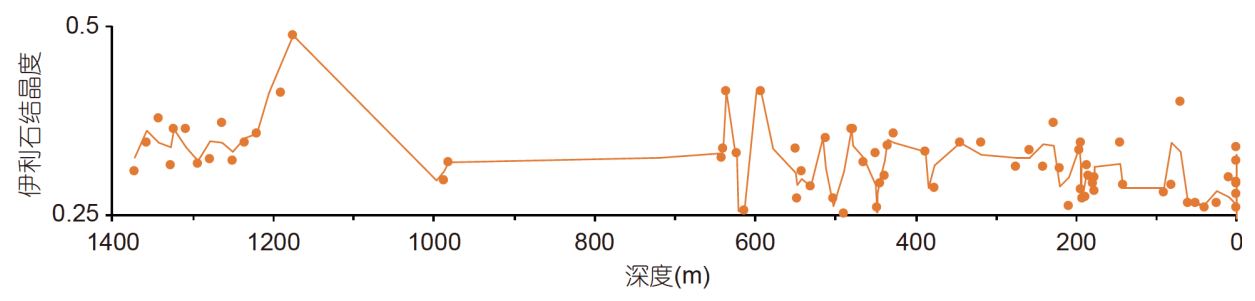

图 12 渭河盆地新生代沉积序列剔除含坡缕石样品的伊利石结晶度

拟合线为三点平滑结果 
就可以发生, 不依赖于特定的气候(Chamley, 1989); (2) 云母类矿物中等风化条件下形成贝得石．渭河盆地较 少见到火山灰、玻璃质凝灰岩等，且周边秦岭山脉广 泛出露花岗岩(王晓霞等, 2015), 因此, 暂不认为渭河 盆地蒙皇石矿物的形成与火山灰有关.

在排除火山灰成因的蒙㿝石后，蒙㿝石的形成需 要一定的气候条件: (1) 蒙皇石由伊利石等前体物质 经化学风化作用, 在干湿气候交替变化下形成, 因此 在温带地区或者干旱半干旱的条件下，蒙皇石与伊利 石、绿泥石的比例可以来代表化学风化作用的强度, 比例越高, 指示化学风化作用越强, 气候可能更偏暖湿 (Zhang和Guo, 2014; Liu等, 2020); (2) 当达到较大的降 水量时, 由于淋滤作用的加强, 蒙㿝石相对含量随着降 水量的增大而逐渐减小，同时伴随高岭石等代表更强 化学风化作用的产物形成(Singer, 1980); (3) 在相似的 气候条件下, 蒙皇石在低洼的地形, 排水不畅的地区, 由于水的传输更慢, 溶液离子富集, 同时植物可能向地 表迁移钾和硅元素导致蒙㿝石含量增多(Velde和Meunier, 2008).

渭河盆地始新世以来河湖相沉积物黏土矿物以蒙 皇石和伊利石为主, 高岭石含量普遍较低, 平均含量为 $4.1 \%$, 是泥质矿物组合中的次要成分，表明渭河盆地 地区的风化强度不足以形成大量的高岭石．同时，由 于红河组晚期、白鹿塬组、寇家村组可能有了不同程 度的成岩作用，由于成岩作用伊利石的改造晶型更好， 导致伊利石结晶度降低以及蒙皇石向伊利石一定程度 的转变(Bjørlykke, 1998), 实际流域风化导致的蒙皇石 含量与伊利石结晶度可能更高, 也解释了当前蒙皇石 (含伊蒙混层)与伊利石和绿泥石的比例与伊利石结晶 度似乎不太一致的趋势. 因此, 自红河组以来伊利石结 晶度下降的趋势会更加明显.

从渭河盆地沉积演化特征来看, 红河组以紫红色 泥岩夹黄色、灰绿色砂岩为主，可能是浅水环境下的 湖相沉积, 而白鹿塬组转变为以灰白色厚层块状砂岩 夹棕红色粉砂质泥岩的滨湖相沉积(鹿化煜等，2018). 结合前人钻井及野外观察资料，红河组至白鹿塬组湖 泊萎缩变成两个浅湖区(李智超等, 2015). 因此, 渭河 盆地黏土矿物揭示的红河组到白鹿塬组化学风化明显 减弱, 与沉积环境转变相对应, 可能是降水减少的结 果. 早、中渐新世沉积间断之后，蓝田地区在中新世 冷水沟期再次接受沉积. 此后的沉积序列主要为灰
白、灰黄砂岩、砾岩和浅棕红色泥岩、粉砂岩的旋回 变化，是一个湖相、河流相、冲积相周期性旋回的沉 积体系，并在晚中新世以来接受风成红黏土堆积. 我 们黏土矿物分析揭示的化学风化强度自中新世冷水 沟、寇家村组以来阶段性减弱, 可能是东亚季风降水 量在构造时间尺度上阶段性减少的体现.

\section{2 古近纪与新近纪东亚气候变化}

渭河盆地黏土矿物以蒙皇石和伊利石为主，虽然 黏土矿物相对含量可能受到母岩、地貌部位等非气候 因素的影响，但总的来说，相比于其他西北地区的盆 地，渭河盆地蒙㿝石含量仍处于较高值，更不同于塔 里木盆地等干旱区伊利石、绿泥石主控的黏土矿物类 型(图13). 因此, 可能表明古近纪渭河盆地相较于西北 地区较为湿润. 同时, 渭河盆地始新世较强的化学风 化，以及大面积的淡水湖泊沉积，表明其并非长期处 于干旱带内. Quan等(2014)结合动植物化石和对煤层 与蒸发岩的新解释, 同样认为早期的干旱带不存在. 早先认为中国北方盆地中大量发育的红层为沙漠或者 热带草原的干旱气候(Sun和Wang，2005)，而Quan等 (2014)认为红层在各气候带的湖相、三角洲相、沙漠 等非海相沉积均存在，认为其仅代表氧化而非干旱条 件下的产物. 红层也有可能在类似于中国南方高温高 降雨的气候条件下形成(孙文峰等，2017). 因此，东亚 古近纪可能存在类似于新近纪的季风格局.

在浅湖环境下，晚始新世到渐新世渭河盆地黏土 矿物伊利石结晶度和伊利石化学指数的降低指示了较 小尺度气候变干, 化学风化减弱的过程. 此时期渭河盆 地蓝田地区沉积相发生明显的变化, 由浅湖沉积转变 为滨湖-浅湖交替沉积. 因此，晚始新世到渐新世渭河 盆地湖盆的萎缩，虽然在一定程度上可能受到构造作 用的影响, 但是气候演变起主导作用. 深海氧同位素 记录表明, 约34.0 33.5Ma“温室”地球进入“冰室”地球, 气候变冷, 南极冰盖增长(Zachos等, 2008), 全球海平面 下降(Westerhold等，2020)，大气二氧化碳浓度显著降 低(Pearson等, 2009; Pagani等, 2011). 中亚和青藏高原 北部的西宁盆地(Dupont-Nivet等, 2007; Zhang和Guo, 2014)、塔里木盆地(Wang等，2013)、准噶尔盆地 (Zhang等，2012; Sun等，2014)、柴达木盆地(Ye等, 2018)、酒泉盆地(苗运法等，2008)等沉积记录均揭示 了气候变化对于EOT降温事件的响应. 从长期趋势来 


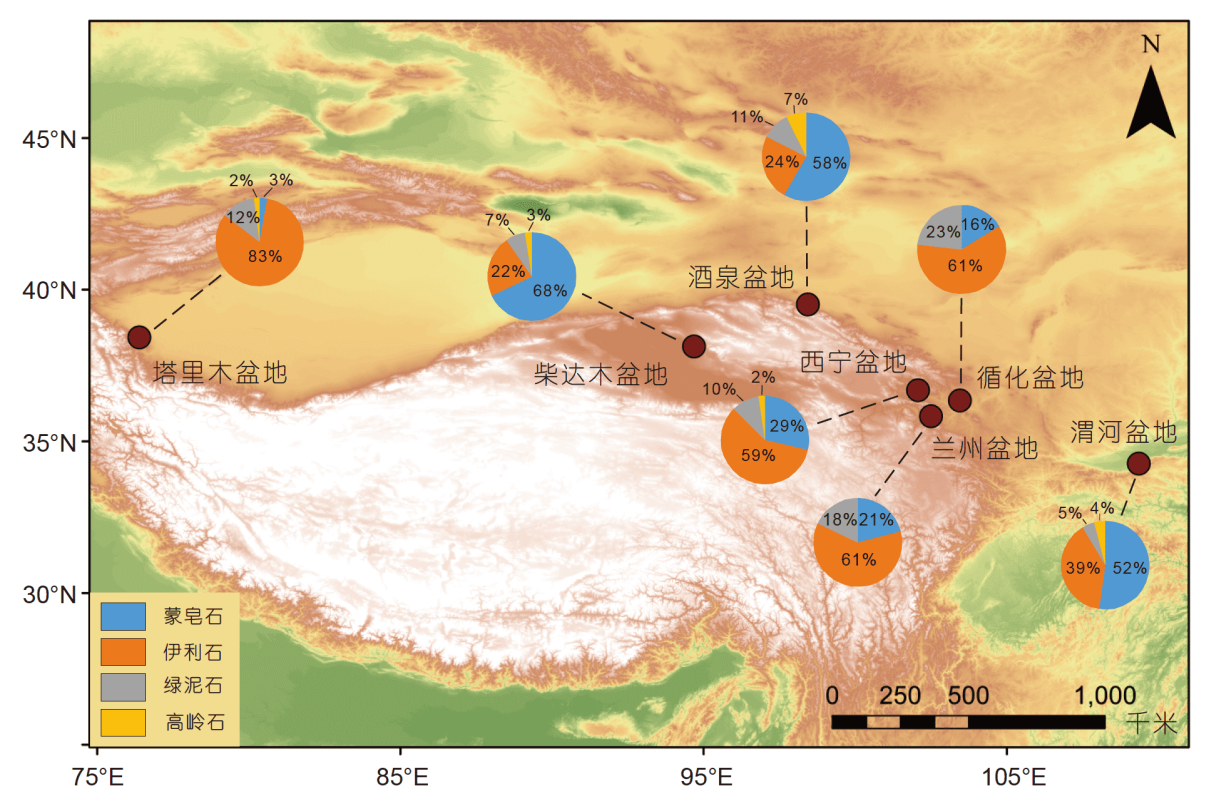

图 13 中国北方各盆地黏土矿物均一化相对含量

详细数据来源见表2, 循化盆地引自Liu等(2019); 酒泉盆地引自Liu等(2020); 西宁盆地引自Yang等(2019)、Fang等(2019)、Zhang和Guo (2014)、胡涁等(2019); 柴达木盆地引自Fang等(2019); 塔里木盆地引自Wang C等(2013b); 兰州盆地引自邓焰平等(2010)

表 2 中国北方各盆地不同时代不同剖面黏土矿物相对含量

\begin{tabular}{cccccccc}
\hline 盆地 & 剖面 & 时代(Ma) & 蒙㿝石(\%) & 伊利石 $(\%)$ & 绿泥石 $(\%)$ & 高岭石 $(\%)$ & 参考文献 \\
\hline 渭河盆地 & 见文中 & $45 ~ 0$ & 52.3 & 39.1 & 4.5 & 4.1 & 本文 \\
循化盆地 & 羊圈沟 & $28 \sim 13$ & 16.2 & 60.6 & 23.2 & 0 & Liu等, 2019 \\
酒泉盆地 & 石羊圈、老君庙 & $24 \sim 0$ & 57.5 & 23.9 & 10.2 & 7.1 & Liu等, 2020 \\
西宁盆地 & 莫家庄 & $13 \sim 5$ & 49.1 & 35.6 & 8.9 & 6.4 & Yang等, 2019 \\
西宁盆地 & 谢家 & $52 ~ 26$ & 55.9 & 33.5 & 9.9 & 0.7 & Fang等, 2019 \\
西宁盆地 & 塔山 & $36 ~ 33$ & 7.2 & 80.0 & 12.9 & 0 & Zhang和Guo, 2014 \\
西宁盆地 & 西箕沟 & $52 ~ 34$ & 2.0 & 87.0 & 9.0 & 2.0 & 胡涁等, 2019 \\
柴达木盆地 & 红柳沟 & $53 ~ 26$ & 68.0 & 22.3 & 7.2 & 2.5 & Fang等, 2019 \\
塔里木盆地 & 其木干 & 古近纪 & 2.9 & 82.6 & 12.4 & 2.1 & Wang等, 2013 \\
兰州盆地 & 永登 & 晚古新世到早渐新世 & 21.0 & 61.0 & 18.0 & 0 & 邓焰平等, 2010 \\
\hline
\end{tabular}

看，西宁盆地和柴达木盆地同样记录了古近纪化学风 化强度随全球温度下降而减弱的过程(Fang等，2019), 因此，渭河流域古近纪后期化学风化强度的减弱，是 一个大区域而非局域的气候变化过程，可能与全球海 洋温度的降低减少大陆内部的水分供应、同时伴随冰 量的增加、海平面的下降、特提斯海的退缩使得大陆 内部干旱加剧 $(\mathrm{Lu}, 2015)$ 有关.

基于上述讨论，渭河盆地沉积物伊利石结晶度自 中新世寇家村组以来阶段性下降, 表明中新世以来化
学风化强度逐渐减弱. 同时, 中国北方风成沉积的分 布、粉尘沉积速率和平均粒径揭示了晚新生代东亚地 区在15 13、8 7、3.6 2.6、1.2 0.8Ma阶段性的干旱 化历程(Lu等, 2010; 鹿化暗和郭正堂, 2013; Fang等, 2020). 中国南海沉积物ODP1148的主微量元素包括 $\mathrm{Al} / \mathrm{Ti} 、 \mathrm{Al} / \mathrm{K} 、 \mathrm{Rb} / \mathrm{Sr}$ 和 $\mathrm{La} / \mathrm{Lu}$ (Li等, 2003)和CIA(Wei等, 2006) 以及ODP1146沉积物的黏土矿物和陆源物质积 累速度(MAR)等分析结果认为(图9e、9f), 东亚季风自 17.2 15.5Ma以来阶段性减弱(Wan等，2007; Clift等, 
2014). 另外，东亚季风区孢粉学的证据显示自 17 14Ma至5Ma降水逐渐下降的趋势(Jiang 和Ding, 2008; Miao等, 2012). 而西宁盆地、酒泉盆地、循化盆 地等同样记录了新近纪化学风化强度随温度的下降而 减弱(Liu等, 2019; Yang等, 2019; Liu等, 2020). 因此, 渭 河盆地中新世以来化学风化强度的阶段性减弱, 可能 与东亚季风和干旱区气候耦合同步阶段性变化有关.

\section{6 结论}

基于渭河盆地新生代河湖相沉积序列的黏土矿物 分析, 重建了中始新世晚期以来的东亚气候变化过程. 渭河盆地新生代河湖相沉积物黏土矿物以蒙皇石和伊 利石为主, 绿泥石、高岭石次之. 伊利石结晶度、伊利 石化学指数、蒙皇石与伊利石和绿泥石的比例指示了 在半干旱半湿润的环境下，中始新世晚期红河组以来 化学风化阶段性减弱的演化特征, 表明中晚始新世渭 河流域可能处于较为湿润的环境下. 坡缕石的出现可 能受到早期较弱的成岩作用控制, 并无明确气候意义. 黏土矿物分析揭示, 古近纪以来, 随着全球温度的降低 渭河盆地风化强度减弱, 东亚季风气候阶段性演化并 在第四纪变干. 另外, 渭河盆地古近纪晚始新世到渐 新世气候变干可能是对全球变冷事件EOT的响应.

致谢 感谢庞奖励教授、周亚利副教授、王翰林博士、 张红艳高级工程师、胡镕副教授、赵琳博士、雷昉、黄 子唅、胥勤勉、王菁菁、陈瑶、梁承弘、杨帆、董小 义、郁晓春、胡少磊、何静、高鉴等在野外采样、沉积 相识别和实验室测试的帮助.

\section{参考文献}

邓焰平, 洪汉烈, 殷科, 徐耀明, 杜鹃, 张克信. 2010. 兰州盆地永登剖 面晚古新世-早渐新世沉积物中黏土矿物的特征及其古气候指示 意义. 现代地质, 24: 793-800

郭正堂, 彭淑贞. 2007. 风成三趾马红土与第四纪黄土的黏土矿物组 成异同及其环境意义. 第四纪研究, 27: 277-285

郭正堂. 2017. 黄土高原见证季风和荒漠的由来. 中国科学: 地球科 学, 47: 421-437

胡森, 张春霞, 吴海斌, 郝青振, 郭正堂. 2019. 西宁盆地始新世河湖 相沉积序列黏土矿物组合特征及其古环境意义. 中国科学: 地球 科学, 49: 569-583

黄思静. 1990. 混层伊利石-蒙脱石的鉴定及其成岩意义. 岩相古地
理, (5): 23-29

季峻峰, 陈骏, 王洪涛. 1997. 陕西洛川黄土-古土壤剖面中伊利石结 晶度一一黄土物质来源和古气候环境的指示. 地质论评，43： 181-185

贾兰坡, 张玉萍, 黄万波, 汤英俊, 计宏祥, 尤玉柱, 丁素因, 黄学诗. 1966. 陕西蓝田新生界现场会议论文集. 北京: 科学出版社. 311 李智超, 李文厚, 李永项, 李玉宏, 韩伟, 闻金华, 陈萌, 秦智. 2015. 渭 河盆地新生代沉积相研究. 古地理学报, 17: 529-540

龙利群, 方小敏, 苗运法, 白艳, 王永莉. 2011. 新生代全球变冷背景 下北部青藏高原变冷和干旱化事件：西宁盆地早第三纪沉积物 中正构烷烃和狍粉的记录. 科学通报, 56: 1221-1231

鹿化显, 郭正堂. 2013. 晚新生代东亚气候变化: 进展与问题. 中国科 学: 地球科学, 43: 1907-1918

鹿化㫫, 张瀚之, 王逸超, 赵琳, 王翰林, 孙文峰, 张红艳. 2018. 渭河 盆地新生代沉积序列与亚洲季风气候起源演化. 第四纪研究, 38: 1057-1067

苗运法, 方小敏, 宋之琛, 吴福莉, 韩文霞. 2008. 青藏高原北部始新 世孢粉记录与古环境变化. 中国科学D辑: 地球科学, 38: 187-196 孟庆任. 2017. 秦岭的由来. 中国科学: 地球科学, 47: 412-420

强小科, 安芷生, 宋友桂, 常宏, 孙有斌, 刘卫国, 敖红, 董吉宝, 符超 峰, 吴枫, 卢风艳, 蔡演军, 周卫健, 曹军瀷, 徐新文, 艾莉. 2010. 晚 渐新世以来中国黄土高原风成红黏土序列的发现: 亚洲内陆干 早化起源的新记录. 中国科学: 地球科学, 40: 1479-1488

孙文峰, 鹿化显, 王逸超, 冯吟, 王翰林, 李永祥, 吴耕泓, 李姝玥, 蒋 品欣. 2017. 渭河盆地蓝田始新世红河组沉积物特征和古环境记 录. 高校地质学报, 23: 533-544

王先彦, 鹿化显, 季峻峰, 王晓勇, 赵景波, 黄宝春, 李珍. 2006. 青藏 高原东北缘中新世红色土状堆积序列的成因及其对亚洲干旱过 程的指示. 中国科学D辑: 地球科学, 36: 261-272

王晓霞, 王涛, 张成立. 2015. 秦岭造山带花岗质岩浆作用与造山带 演化. 中国科学: 地球科学, 45: 1109-1125

薛祥煦. 1981. 陕西渭南一早更新世哺乳动物群及其层位. 古脊椎动 物与古人类, $19: 35-44$

岳乐平, Heller F, 邱占祥, 张莉, 颉光普, 邱铸鼎, 张云翔. 2000. 兰州 盆地第三系磁性地层年代与古环境记录. 科学通报, 45: 19982003

张国伟, 张本仁, 袁学诚, 肖庆辉. 2001. 秦岭造山带与大陆动力学. 北京: 科学出版社. 863

张军, 颔光普, 李吉均, 宋春晖, 赵志军. 2011. 甘肃秦安崖湾剖面新 近纪哺乳动物化石及其生态环境特征. 第四纪研究, 31: 614-621

张玉萍, 黄万波, 汤英俊, 计宏祥, 尤玉柱, 童永生, 丁素因, 黄学诗, 郑家坚. 1978. 陕西蓝田地区新生界. 北京: 科学出版社. 60

赵琳, 鹿化显, 唐领余. 2018. 渭河盆地新生代狍粉组合与植被演化 特征. 第四纪研究, 38: 1083-1093

朱敏, 丁仲礼, 王旭, 陈祚伶, 蒋汉朝, 董欣欣, 季军良, 唐自华, 罗攀. 2010. 南阳盆地PETM事件的高分辨率碳同位素记录. 科学通报, 
55: $2400-2405$

An Z S. 2000. The history and variability of the East Asian paleomonsoon climate. Quat Sci Rev, 19: 171-187

Ao H, Dupont-Nivet G, Rohling E J, Zhang P, Ladant J B, Roberts A P, Licht A, Liu Q, Liu Z, Dekkers M J, Coxall H K, Jin Z, Huang C, Xiao G, Poulsen C J, Barbolini N, Meijer N, Sun Q, Qiang X, Yao J, An Z. 2020. Orbital climate variability on the northeastern Tibetan Plateau across the Eocene-Oligocene transition. Nat Commun, 11: 5249

Biscaye P E. 1965. Mineralogy and sedimentation of recent deep-sea clay in the Atlantic Ocean and adjacent seas and oceans. Geol Soc Am Bull, 76: 803

Bjørlykke K. 1998. Clay mineral diagenesis in sedimentary basins-A key to the prediction of rock properties. Examples from the North Sea Basin. Clay Miner, 33: 15-34

Bougeois L, Dupont-Nivet G, de Rafélis M, Tindall J C, Proust J N, Reichart G J, de Nooijer L J, Guo Z, Ormukov C. 2018. Asian monsoons and aridification response to Paleogene sea retreat and Neogene westerly shielding indicated by seasonality in Paratethys oysters. Earth Planet Sci Lett, 485: 99-110

Caves Rugenstein J K, Chamberlain C P. 2018. The evolution of hydroclimate in Asia over the Cenozoic: A stable-isotope perspective. Earth-Sci Rev, 185: 1129-1156

Chamley H. 1989. Clay Sedimentology. New York: Springer. 623

Clift P D, Wan S M, Blusztajn J. 2014. Reconstructing chemical weathering, physical erosion and monsoon intensity since $25 \mathrm{Ma}$ in the northern South China Sea: A review of competing proxies. Earth-Sci Rev, 130: 86-102

Ding Z L, Rutter N, Han J T, Liu T S. 1992. A coupled environmental system formed at about $2.5 \mathrm{Ma}$ in East Asia. Palaeogeogr Palaeoclimatol Palaeoecol, 94: 223-242

Ding Z L, Sun J M, Yang S L, Liu T S. 1998. Preliminary magnetostratigraphy of a thick eolian red clay-loess sequence at Lingtai, the Chinese Loess Plateau. Geophys Res Lett, 25: 12251228

Dupont-Nivet G, Krijgsman W, Langereis C G, Abels H A, Dai S, Fang X. 2007. Tibetan plateau aridification linked to global cooling at the Eocene-Oligocene transition. Nature, 445: 635-638

Fang X, An Z, Clemens S C, Zan J, Shi Z, Yang S, Han W. 2020. The 3.6-Ma aridity and westerlies history over midlatitude Asia linked with global climatic cooling. Proc Natl Acad Sci USA, 117: 2472924734

Fang X, Galy A, Yang Y, Zhang W, Ye C, Song C. 2019. Paleogene global cooling - Induced temperature feedback on chemical weathering, as recorded in the northern Tibetan Plateau. Geology, 47: 992-996
Fang X, Zan J, Appel E, Lu Y, Song C, Dai S, Tuo S. 2015. An EoceneMiocene continuous rock magnetic record from the sediments in the Xining Basin, NW China: Indication for Cenozoic persistent drying driven by global cooling and Tibetan Plateau uplift. Geophys J Int, 201: 78-89

Frey M. 1970. Step from diagenesis to metamorphism in pelitic rocks during alpine orogenesis. Sedimentology, 15: 261-279

Guo Z T, Ruddiman W F, Hao Q Z, Wu H B, Qiao Y S, Zhu R X, Peng S Z, Wei J J, Yuan B Y, Liu T S. 2002. Onset of Asian desertification by $22 \mathrm{Myr}$ ago inferred from loess deposits in China. Nature, 416: 159-163

Guo Z T, Sun B, Zhang Z S, Peng S Z, Xiao G Q, Ge J Y, Hao Q Z, Qiao Y S, Liang M Y, Liu J F, Yin Q Z, Wei J J. 2008. A major reorganization of Asian climate by the early Miocene. Clim Past, 4: 153-174

Gylesjö S, Arnold E. 2006. Clay mineralogy of a red clay-loess sequence from Lingtai, the Chinese Loess Plateau. Glob Planet Change, 51: 181-194

Jiang H, Ding Z. 2008. A 20 Ma pollen record of East-Asian summer monsoon evolution from Guyuan, Ningxia, China. Palaeogeogr Palaeoclimatol Palaeoecol, 265: 30-38

Kaakinen A. 2005. A terrestrial sequence in Lantian-A window into the late Neogene palaeoenvironments of Northern China. Department of Earth Sciences. University of Helsinki

Kaakinen A, Lunkka J P. 2003. Sedimentation of the Late Miocene Bahe Formation and its implications for stable environments adjacent to Qinling mountains in Shaanxi, China. J Asian Earth Sci, 22: 67-78

Li X, Wei G, Shao L, Liu Y, Liang X, Jian Z, Sun M, Wang P. 2003. Geochemical and $\mathrm{Nd}$ isotopic variations in sediments of the South China Sea: A response to Cenozoic tectonism in SE Asia. Earth Planet Sci Lett, 211: 207-220

Li Y, Song Y, Zeng M, Lin W, Orozbaev R, Cheng L, Chen X, Halmurat T. 2018. Evaluating the paleoclimatic significance of clay mineral records from a late Pleistocene loess-paleosol section of the Ili Basin, Central Asia. Quat Res, 89: 660-673

Licht A, van Cappelle M, Abels H A, Ladant J B, Trabucho-Alexandre J, France-Lanord C, Donnadieu Y, Vandenberghe J, Rigaudier T, Lécuyer C, Terry Jr D, Adriaens R, Boura A, Guo Z, Soe A N, Quade J, Dupont-Nivet G, Jaeger J J. 2014. Asian monsoons in a late Eocene greenhouse world. Nature, 513: 501-506

Liu J, Zhang P, Lease R O, Zheng D, Wan J, Wang W, Zhang H. 2013. Eocene onset and late Miocene acceleration of Cenozoic intracontinental extension in the North Qinling range-Weihe graben: Insights from apatite fission track thermochronology. Tectonophysics, 584: 281-296 
Liu T, Ding Z. 1998. Chinese loess and the paleomonsoon. Annu Rev Earth Planet Sci, 26: 111-145

Liu Y, Song C, Meng Q, He P, Yang R, Huang R, Chen S, Wang D, Xing Z. 2020. Paleoclimate change since the Miocene inferred from clay-mineral records of the Jiuquan Basin, NW China. Palaeogeogr Palaeoclimatol Palaeoecol, 550: 109730

Liu Z, Hong H, Wang C, Han W, Yin K, Ji K, Fang Q, Algeo T. 2019. Oligocene-Miocene (28-13 Ma) climato-tectonic evolution of the northeastern Qinghai-Tibetan Plateau evidenced by mineralogical and geochemical records of the Xunhua Basin. Palaeogeogr Palaeoclimatol Palaeoecol, 514: 98-108

Liu Z, Zhao Y, Colin C, Stattegger K, Wiesner M G, Huh C A, Zhang Y, Li X, Sompongchaiyakul P, You C F, Huang C Y, Liu J T, Siringan F P, Le K P, Sathiamurthy E, Hantoro W S, Liu J, Tuo S, Zhao S, Zhou S, He Z, Wang Y, Bunsomboonsakul S, Li Y. 2016. Source-to-sink transport processes of fluvial sediments in the South China Sea. Earth-Sci Rev, 153: 238-273

Lu H Y. 2015. Driving force behind global cooling in the Cenozoic: An ongoing mystery. Sci Bull, 60: 2091-2095

Lu H Y, Wang X Y, Li L P. 2010. Aeolian sediment evidence that global cooling has driven late Cenozoic stepwise aridification in central Asia. Geol Soc Lond Spec Publ, 342: 29-44

Lu H Y, Wang X Y, Wang Y, Zhang X J, Yi S W, Wang X Y, Stevens T, Kurbanov R, Marković S B. 2021. Chinese loess and the Asian monsoon: What we know and what remains unknown. Quat Int, doi: 10.1016/j.quaint.2021.04.027

Ma Y, Fan M, Lu Y, Liu H, Zhang S, Liu X. 2019. Stable isotope record of middle Eocene summer monsoon and its instability in eastern China. Glob Planet Change, 175: 103-112

Miao Y, Herrmann M, Wu F, Yan X, Yang S. 2012. What controlled Mid-Late Miocene long-term aridification in Central Asia?-Global cooling or Tibetan Plateau uplift: A review. Earth-Sci Rev, 112: $155-172$

Pagani M, Huber M, Liu Z, Bohaty S M, Henderiks J, Sijp W, Krishnan

S, DeConto R M. 2011. The role of carbon dioxide during the onset of Antarctic glaciation. Science, 334: 1261-1264

Pearson P N, Foster G L, Wade B S. 2009. Atmospheric carbon dioxide through the Eocene-Oligocene climate transition. Nature, 461: $1110-1113$

Petschick R. 2000. MacDiff 4.2.2: A software of calculating concentration of minerals for XRD data. Http://servermac. geologie.un-frankfurt.de/ Rainer.html

Quan C, Liu Y S C, Utescher T. 2012a. Paleogene temperature gradient, seasonal variation and climate evolution of northeast China. Palaeogeogr Palaeoclimatol Palaeoecol, 313-314: 150-161

Quan C, Liu Y S C, Utescher T. 2012b. Eocene monsoon prevalence over China: A paleobotanical perspective. Palaeogeogr Palaeoclimatol Palaeoecol, 365-366: 302-311

Quan C, Liu Y S, Utescher T. 2011. Paleogene evolution of precipitation in Northeastern China supporting the Middle Eocene intensification of the East Asian monsoon. Palaios, 26: 743-753

Quan C, Liu Z, Utescher T, Jin J, Shu J, Li Y, Liu Y S C. 2014. Revisiting the Paleogene climate pattern of East Asia: A synthetic review. Earth-Sci Rev, 139: 213-230

Reynolds R C. 1980. Interstratified clay minerals. London: In: Brindley G W, Brown G, eds. Mineralogical Society. Elsevier. 249-303

Roe G H, Ding Q, Battisti D S, Molnar P, Clark M K, Garzione C N. 2016. A modeling study of the response of Asian summertime climate to the largest geologic forcings of the past $50 \mathrm{Ma}$. J Geophys Res-Atmos, 121: 5453-5470

Singer A. 1980. The paleoclimatic interpretation of clay minerals in soils and weathering profiles. Earth-Sci Rev, 15: 303-326

Singer A, Galan E. 2011. Developments in Palygorskite-Sepiolite Research, Volume 3. Elsevier. 520

Song B, Zhang K, Lu J, Wang C, Xu Y, Greenough J. 2013. The middle Eocene to early Miocene integrated sedimentary record in the Qaidam Basin and its implications for paleoclimate and early Tibetan Plateau uplift. Can J Earth Sci, 50: 183-196

Song B, Zhang K, Zhang L, Ji J, Hong H, Wei Y, Xu Y, Algeo T J, Wang C. 2018. Qaidam Basin paleosols reflect climate and weathering intensity on the northeastern Tibetan Plateau during the Early Eocene Climatic Optimum. Palaeogeogr Palaeoclimatol Palaeoecol, 512: 6-22

Spicer R A, Yang J, Herman A B, Kodrul T, Maslova N, Spicer T E V, Aleksandrova G, Jin J. 2016. Asian Eocene monsoons as revealed by leaf architectural signatures. Earth Planet Sci Lett, 449: 61-68

Sun D H, Shaw J, An Z S, Cheng M Y, Yue L P. 1998. Magnetostratigraphy and paleoclimatic interpretation of a continuous 7.2 Ma Late Cenozoic Eolian sediments from the Chinese Loess Plateau. Geophys Res Lett, 25: 85-88

Sun J, Ni X, Bi S, Wu W, Ye J, Meng J, Windley B F. 2014. Synchronous turnover of flora, fauna and climate at the EoceneOligocene Boundary in Asia. Sci Rep, 4: 7463

Sun X, Wang P. 2005. How old is the Asian monsoon system?Palaeobotanical records from China. Palaeogeogr Palaeoclimatol Palaeoecol, 222: 181-222

Tierney J E, Poulsen C J, Montañez I P, Bhattacharya T, Feng R, Ford H L, Hönisch B, Inglis G N, Petersen S V, Sagoo N, Tabor C R, Thirumalai K, Zhu J, Burls N J, Foster G L, Goddéris Y, Huber B T, Ivany L C, Kirtland Turner S, Lunt D J, McElwain J C, Mills B J W, Otto-Bliesner B L, Ridgwell A, Zhang Y G. 2020. Past climates inform our future. Science, 370: eaay3701 
Velde B, Meunier A. 2008. The Origin of Clay Minerals in Soils and Weathered Rocks. Berlin, Heidelberg: Springer. 406

Wan S, Li A, Clift P D, Stuut J B W. 2007. Development of the East Asian monsoon: Mineralogical and sedimentologic records in the northern South China Sea since 20 Ma. Palaeogeogr Palaeoclimatol Palaeoecol, 254: 561-582

Wang B, Zheng H, He Z, Wang P, Kaakinen A, Zhou X. 2014. Middle Miocene eolian sediments on the southern Chinese Loess Plateau dated by magnetostratigraphy. Palaeogeogr Palaeoclimatol Palaeoecol, 411: 257-266

Wang C, Adriaens R, Hong H, Elsen J, Vandenberghe N, Lourens L J, Gingerich P D, Abels H A. 2017. Clay mineralogical constraints on weathering in response to early Eocene hyperthermal events in the Bighorn Basin, Wyoming (Western Interior, USA). Geol Soc Am Bull, 129: 997-1011

Wang C, Hong H, Li Z, Liang G, Xie J, Song B, Song E, Zhang K. 2013a. Climatic and tectonic evolution in the North Qaidam since the Cenozoic: Evidence from sedimentology and mineralogy. J Earth Sci, 24: 314-327

Wang C, Hong H, Li Z, Yin K, Xie J, Liang G, Song B, Song E, Zhang K. 2013b. The Eocene-Oligocene climate transition in the Tarim Basin, Northwest China: Evidence from clay mineralogy. Appl Clay Sci, 74: 10-19

Wang D, Lu S, Han S, Sun X, Quan C. 2013. Eocene prevalence of monsoon-like climate over eastern China reflected by hydrological dynamics. J Asian Earth Sci, 62: 776-787

Wang H, Lu H, Zhao L, Zhang H, Lei F, Wang Y. 2019. Asian monsoon rainfall variation during the Pliocene forced by global temperature change. Nat Commun, 10: 5272

Wang Y, Lu H, Wang K, Wang Y, Li Y, Clemens S, Lv H, Huang Z, Wang H, Hu X, Lu F, Zhang H. 2020. Combined high- and lowlatitude forcing of East Asian monsoon precipitation variability in the Pliocene warm period. Sci Adv, 6: eabc2414

Weaver C E. 1989. Clays, Muds, and Shales. Amsterdam: Elsevier Science. 785

Wei G, Li X H, Liu Y, Shao L, Liang X. 2006. Geochemical record of chemical weathering and monsoon climate change since the early Miocene in the South China Sea. Paleoceanography, 21: PA4214
Westerhold T, Marwan N, Drury A J, Liebrand D, Agnini C, Anagnostou E, Barnet J S K, Bohaty S M, De Vleeschouwer D, Florindo F, Frederichs T, Hodell D A, Holbourn A E, Kroon D, Lauretano V, Littler K, Lourens L J, Lyle M, Pälike H, Röhl U, Tian J, Wilkens R H, Wilson P A, Zachos J C. 2020. An astronomically dated record of Earth's climate and its predictability over the last 66 million years. Science, 369: 1383-1387

Xiao G Q, Abels H A, Yao Z Q, Dupont-Nivet G, Hilgen F J. 2010. Asian aridification linked to the first step of the Eocene-Oligocene climate Transition (EOT) in obliquity-dominated terrestrial records (Xining Basin, China). Clim Past, 6: 501-513

Yang R, Yang Y, Fang X, Ruan X, Galy A, Ye C, Meng Q, Han W. 2019. Late Miocene intensified tectonic uplift and climatic aridification on the Northeastern Tibetan Plateau: Evidence from clay mineralogical and geochemical records in the Xining Basin. Geochem Geophys Geosyst, 20: 829-851

Ye C, Yang Y, Fang X, Hong H, Wang C, Yang R, Zhang W. 2018. Chlorite chemical composition change in response to the EoceneOligocene climate transition on the northeastern Tibetan Plateau. Palaeogeogr Palaeoclimatol Palaeoecol, 512: 23-32

Zachos J C, Dickens G R, Zeebe R E. 2008. An early Cenozoic perspective on greenhouse warming and carbon-cycle dynamics. Nature, 451: 279-283

Zhang C, Guo Z. 2014. Clay mineral changes across the EoceneOligocene transition in the sedimentary sequence at Xining occurred prior to global cooling. Palaeogeogr Palaeoclimatol Palaeoecol, 411: $18-29$

Zhang R, Kravchinsky V A, Yue L. 2012. Link between global cooling and mammalian transformation across the Eocene-Oligocene boundary in the continental interior of Asia. Int J Earth Sci-Geol Rundsch, 101: 2193-2200

Zhao L, Lu H, Wang H, Meadows M, Ma C, Tang L, Lei F, Zhang H. 2020. Vegetation dynamics in response to evolution of the Asian Monsoon in a warm world: Pollen evidence from the Weihe Basin, central China. Glob Planet Change, 193: 103269

Zheng H, An Z, Shaw J. 1992. New contributions to Chinese PlioPleistocene magnetostratigraphy. Phys Earth Planet Inter, 70: 146153

(责任编委: 胡建芳) 